\title{
Review on Innovative Catalytic Reforming of Natural Gas to Syngas
}

\author{
Salwa A. Ghoneim*, Radwa A. El-Salamony, Seham A. El-Temtamy \\ Egyptian Petroleum Research Institute, Cairo, Egypt \\ Email: "Salwaghoneim70@yahoo.com
}

Received 7 December 2015; accepted 21 February 2016; published 25 February 2016

Copyright (C) 2016 by authors and Scientific Research Publishing Inc.

This work is licensed under the Creative Commons Attribution International License (CC BY). http://creativecommons.org/licenses/by/4.0/

\section{(c) (i) Open Access}

\section{Abstract}

Decreasing supplies of high quality crude oil and increasing demand for high quality distillates have motivated the interest in converting natural gas to liquid fuels, especially with the present boom in natural gas proven reserves. Nevertheless, one major issue is the curtailment of costs incurred in producing synthesis gas from natural gas, which account for approximately $60 \%$ of the costs used in producing liquid fuels. While there are three main routes to convert natural gas to syngas: steam reforming (SMR), partial Oxidation (POX) and auto-thermal reforming (ATR). Significant new developments and improvements in these technologies, established innovative processes to minimize greenhouse gases emission, minimize energy consumption, enhance syngas processes, adjust the desired $\mathrm{H}_{2} / \mathrm{CO}$ ratio and change the baseline economics. This article reviews the state of the art for the reforming of natural gas to synthesis gas taking into consideration all the new innovations in both processes and catalysis.

\section{Keywords}

Natural Gas, Reforming Processes Technology, Syngas, Reforming Catalysts

\section{Introduction}

In the last few years, natural gas, a non-renewable energy source of primary energy, has been utilized as a feed stock for several industrial high value-added productions and also as environmentally clean and easily transportable fuel due to its abundance and enormous surplus in remote areas and underground resources. The use of natural gas causes a rise in global concentration of green house gases [1]. According to the studies of Mackenzie and Mackenzie (1995), the contribution of $\mathrm{CH}_{4}$ and $\mathrm{CO}_{2}$ accounts for three quarters of the total greenhouse effect [2]. In this regard, therefore, extensive efforts are being made to convert greenhouse gases into high valuable products such as syngas and high purity hydrogen.

\footnotetext{
${ }^{*}$ Corresponding author.
} 
Searching for alternative energy sources to replace petroleum based fuels, natural gas has attracted the interest of many researchers and the large amount of methane contained in natural gas has been considered as an input in the production of other high-value products such as syngas and high purity hydrogen.

Syngas, a mixture of $\mathrm{H}_{2}$ and $\mathrm{CO}$, forms the feed stock in the chemical and petrochemical industries for the production of methanol, acetic acid, olefins, gasoline, MTBE, Oxo-alcohols, phosgene and synthetic liquid fuels, etc.

In some cases either $\mathrm{H}_{2}$ or $\mathrm{CO}$ is utilized, for which $\mathrm{H}_{2}$ and $\mathrm{CO}$ are acquired from synthesis gas. The hydrogen is used in fuel cells, in the production of urea and heavy water, etc. However, the biggest consumer of $\mathrm{H}_{2}$ from syngas is ammonia synthesis. Recently it is being planned to utilize the hydrogen as a fuel for non-polluting vehicle. The carbon monoxide is used in the production of paints, plastics, pesticides, insecticides, acetic acid and ethylene glycol, etc.

For the production of clean fuel like hydrogen to be utilized in fuel cells from natural gas, it is first necessary to bring natural gas to a catalytic process called natural gas reforming. This catalytic process is also known as reforming of methane. Syngas can be produced from a variety of primary feedstock such as coal, petroleum coke, biomass, and natural gas. The lowest cost routes for syngas production, however, are based on natural gas [3]. The primary feedstock and reaction routes of syngas production determine the $\mathrm{H}_{2}$ : $\mathrm{CO}$ molar ratio of the syngas (also called syngas ratio), which is important as different end products require different syngas ratios. In general, for DME production, a syngas ratio of 1 is needed, whereas in the case of Fischer-Tropsch synthesis, the required syngas ratio varies from 1 to 2.1 depending on the catalyst and pressure used [4]. Natural gas reforming is based on a catalytic chemical reaction that aims to convert methane, the main constituent of natural gas, to a mixture of hydrogen and carbon monoxide. This mixture of gases $\left(\mathrm{H}_{2}+\mathrm{CO}\right)$, the product of natural gas reforming, is called syngas. Syngas is commonly used in the synthesis of important products.

Figure 1 shows the different indirect routes for the production of chemicals from methane via synthesis gas.

\section{Reforming of Natural Gas}

Natural gas reforming also known as reforming of methane can be accomplished by means of an exothermic or endothermic reaction depending on the chemical process selected to perform the catalytic reforming of methane.

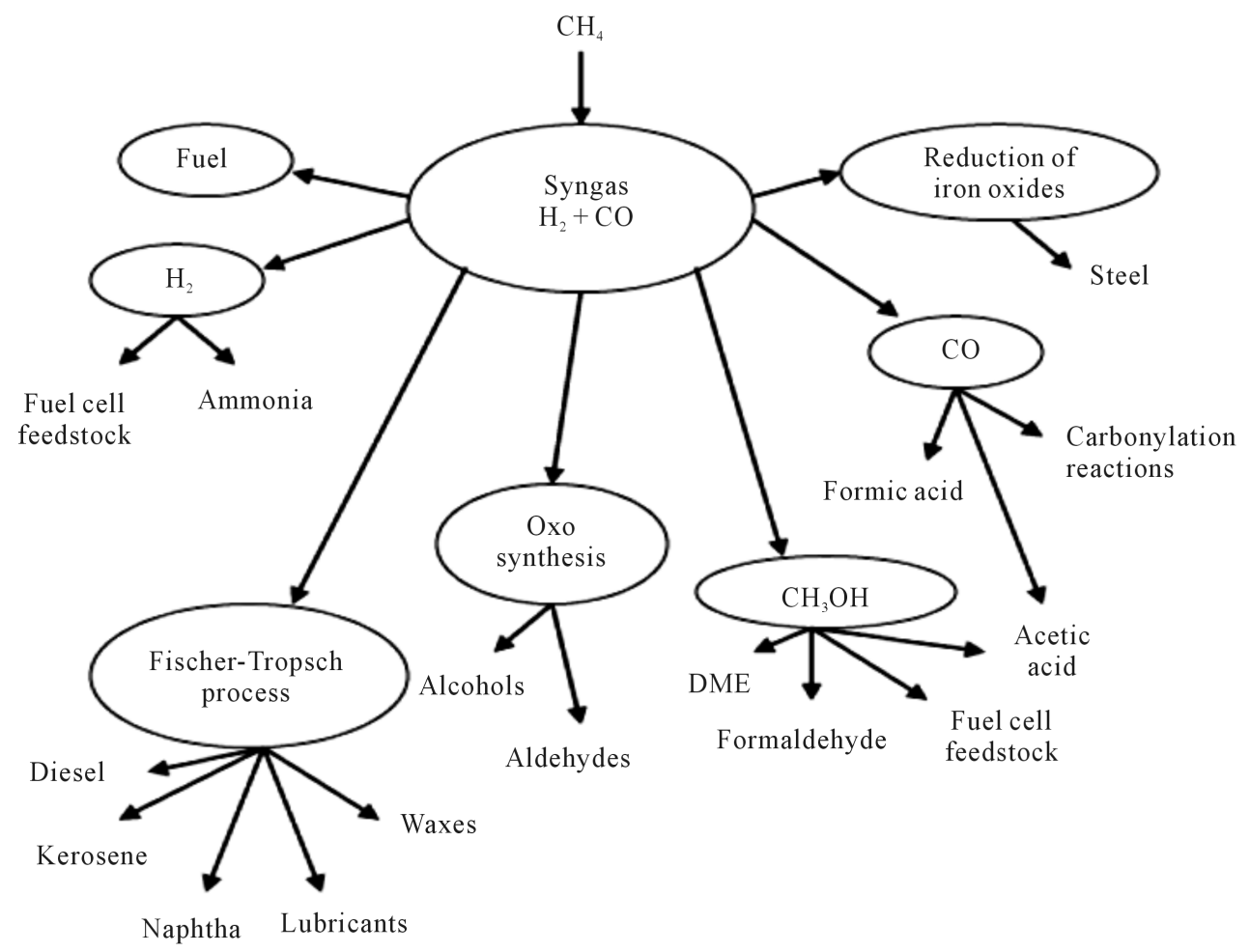

Figure 1. Various indirect routes for the production of useful chemicals from natural gas. 
There are seven reforming processes available for the production of syngas from natural gas, whose major component is methane. These are:

1) Steam Reforming (SMR),

2) Partial Oxidation (POX),

3) Auto Thermal reforming, (ATR),

4) Dry Reforming of methane (DMR),

5) Combined Reforming of methane (CMR),

6) Reforming with Membrane,

7) Tri-reforming of Methane (TMR).

While the top three methods are well established and are widely employed by industry the last four methods are innovations to minimize greenhouse gases emissions, minimize energy consumption and improve the reforming process yields. These methods differ in the composition of syngas produced i.e. their $\mathrm{H}_{2} / \mathrm{CO}$ ratio as shown in Figure 2.

\subsection{Steam Reforming}

Steam reforming or steam methane reforming (SMR) is the reaction where steam and hydrocarbons, such as natural gas or refinery feed stock, react in a reformer at temperature of $800^{\circ} \mathrm{C}-900^{\circ} \mathrm{C}$ and moderate pressure (around $30 \mathrm{bar}$ ) in the presence of metal based catalyst for the production of syngas [5]. Syngas reacts further to give more hydrogen and carbon dioxide via the water gas shift (WGS) reaction, which is a side reaction in steam reforming. Steam reforming of natural gas produces syngas with a $\mathrm{H}_{2}: \mathrm{CO}$ molar ratio close to 3 .

Figure 3 illustrates the tubular steam reformer of Linde Company [6].

$$
\begin{array}{cc}
\mathrm{CH}_{4}+\mathrm{H}_{2} \mathrm{O} \leftrightarrow \mathrm{CO}+3 \mathrm{H}_{2} & \Delta \mathrm{H}_{298}^{\circ}=206.1 \mathrm{~kJ} \cdot \mathrm{mol}^{-1} \\
\mathrm{CO}+\mathrm{H}_{2} \mathrm{O} \leftrightarrow \mathrm{CO}_{2}+\mathrm{H}_{2} & \Delta \mathrm{H}_{298}^{\circ}=-41.2 \mathrm{~kJ} \cdot \mathrm{mol}^{-1}
\end{array}
$$

Most SMR units include two sections, namely a radiant and a convective section. Reforming reactions take place inside the radiant section. In the convective section, heat is recovered from the hot product gases for preheating the reactants feeds and for generating superheated steam.

Because the process of steam reforming of methane is the reforming process that leads to obtaining syngas with the highest $\mathrm{H}_{2} / \mathrm{CO}$ ratio, this type of reforming process is considered ideal to obtain a hydrogen gas flow of

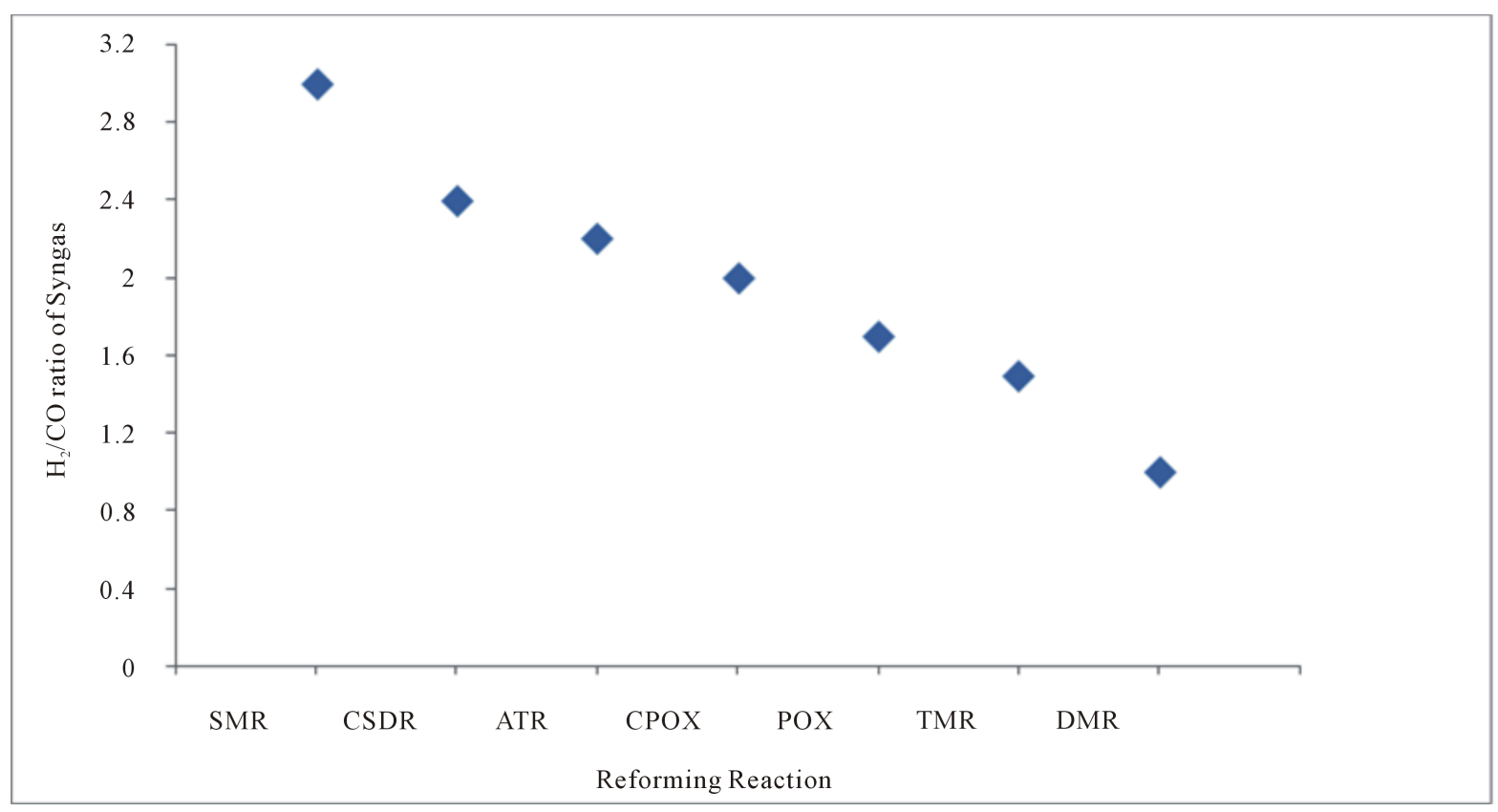

Figure $2 . \mathrm{H}_{2} / \mathrm{CO}$ ratio of syngas from various syngas generators. 


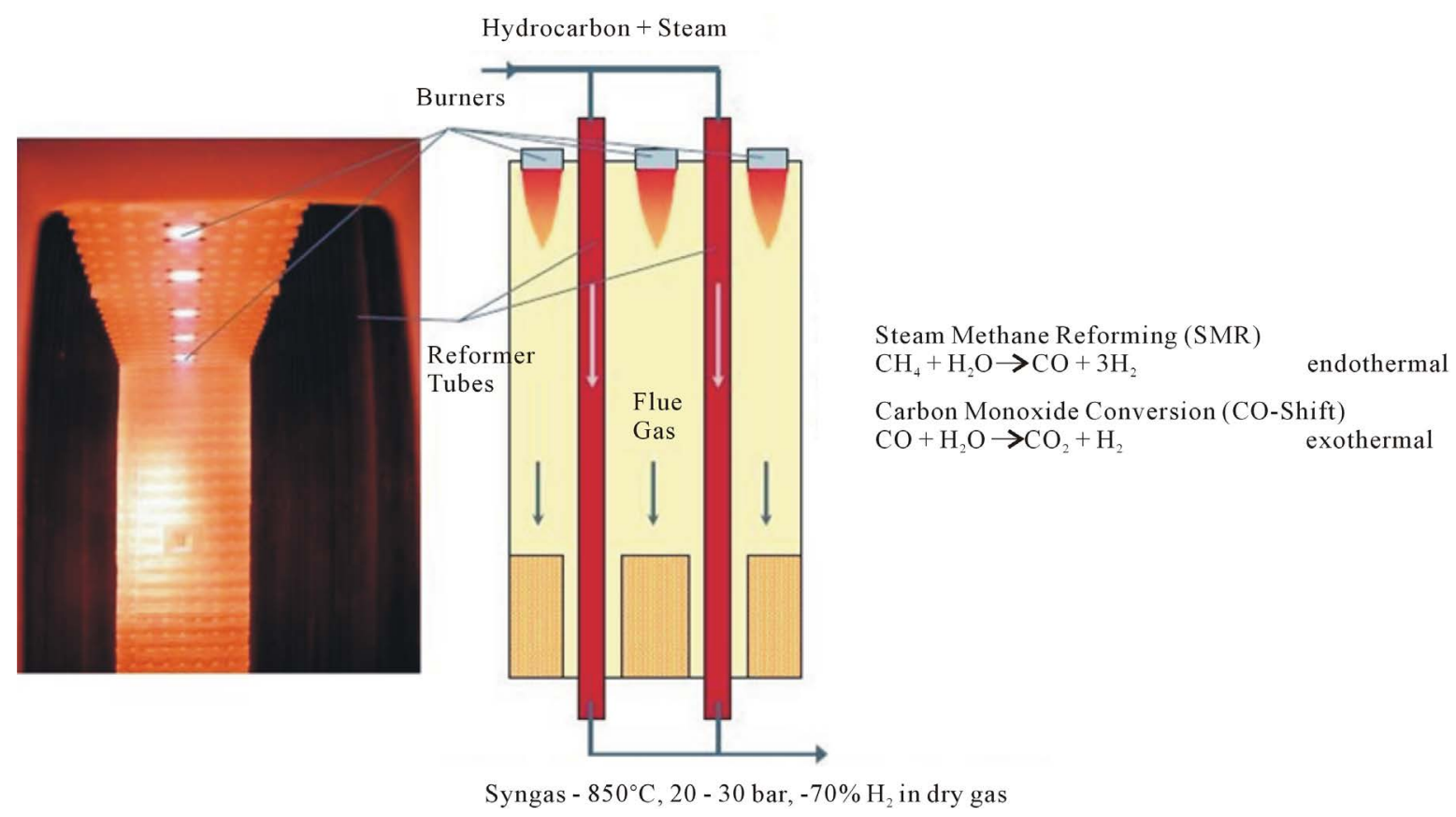

Figure 3. Tubular steam reformer [6].

high purity from syngas. It is the most widely applied method of producing syngas from natural gas and represents $50 \%$ of the global processes of conversion of natural gas for hydrogen production. This percentage reaches $90 \%$ in the U.S. Steam reforming of methane is an endothermic process and, therefore, requires very high temperatures, which makes this process very expensive.

\section{Innovated Steam Reformer}

\section{Heat Exchange Reformers}

Basically, a heat exchange reformer is a steam reformer where the heat required for the reaction is supplied predominantly by convective heat exchange. The heat can be supplied from flue gas or process gas or in principle by any other available hot gas. When the heat and mass balance on the process (catalyst) side only is considered, there is no difference between heat exchange reforming and fired tubular reforming, where the heat transfer is predominantly by radiation. This means that all process schemes using heat exchange reforming will have alternatives where the function of the heat exchange reformer is performed in a fired reformer. The process schemes differ "only”, in the amount of heat in flue gas and/or process gas and in the way this heat is utilized.

Types of heat exchange reformers

Three different concepts for heat exchange reformer design have been commercialized by various companies. The three concepts are illustrated in Figure 4.

Types A and B in Figure 4 can be used with all types of heating gas, whereas type C can only be used when the desired product gas is a mixture of the heating gas and the reformed product gas.

\subsection{Partial Oxidation POX and CPOX}

It occurs when a sub-stoichiometric fuel-air mixture is partially combusted in a high temperature reformer [8], and it produces hydrogen rich syngas. Partial oxidation is an exothermic reaction and, thus, considered more economic than the processes of steam reforming or dry reforming, because it requires a smaller amount of thermal energy. On the other hand, the partial oxidation is considered an expensive process because it requires a flow of pure oxygen. Thus, there is a warning of danger inherent in the process of partial oxidation of methane, since the two reagents $\left(\mathrm{CH}_{4}\right.$ and $\left.\mathrm{O}_{2}\right)$ can cause an explosion if the reaction is not conducted with the necessary care [9].

$$
\mathrm{CH}_{4}+1 / 2 \mathrm{O}_{2} \rightarrow \mathrm{CO}+2 \mathrm{H}_{2} \quad \Delta \mathrm{H}_{298}=-36 \mathrm{~kJ} / \mathrm{mol}
$$




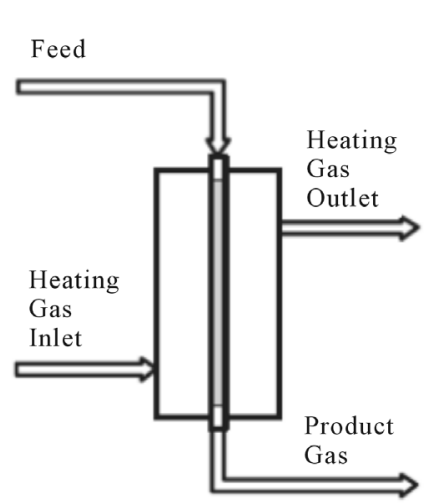

(a)

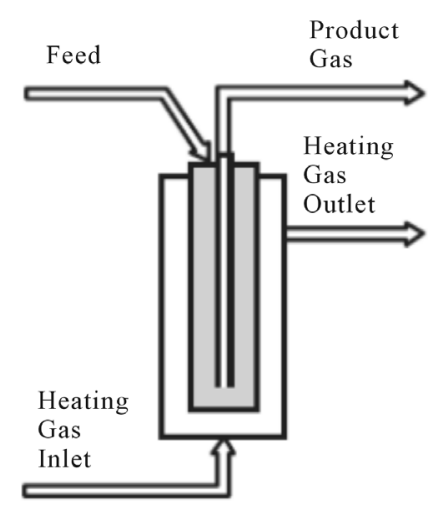

(b)

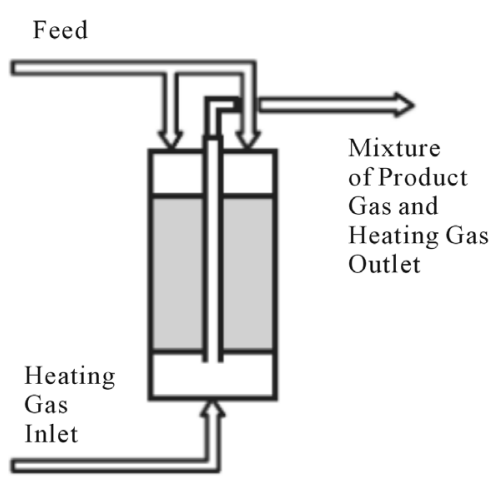

(c)

Figure 4. Different types of heat exchange reformer [7].

The reactor design of POX and CPOX is presented as a scheme in Figure 5.

POX reactor simply comprises two zones, first the flame part where the hydrocarbons, oxygen, and possibly low amounts of steam react together and second a heat exchanger that recovers the excess heat after the reaction.

In non-catalytic partial oxidation, the production of syngas depends on the air-fuel ratio at operating temperature of $1200^{\circ} \mathrm{C}-1500^{\circ} \mathrm{C}$ without a catalyst [10]. A non-catalytic partial oxidation process was developed by Texaco and Shell which results in high syngas yields at high temperature and pressures [11].

The use of catalyst in the production of syngas lowers the required reaction temperature to around $800^{\circ} \mathrm{C}$ $900^{\circ} \mathrm{C}$ [10]. In the CPOX reaction, methane is converted with oxygen (or air) over noble metal (Pt, $\left.\mathrm{Rh}, \mathrm{Ir}, \mathrm{Pd}\right)$ and non-noble metal (Ni, Co) catalysts to syngas in a single step process. CPOX has been studied extensively during the past decade. Many studies have focused on the reaction mechanism [13]; reactor configurations [14]-[16]; reactor simulations [17] [18] as well as novel catalyst synthesis [19] to improve the process efficiency.

Catalytic partial oxidation can be used only if the sulfur content of natural gas is below 50 ppm. Higher sulfur content would poison the catalyst, so non-catalytic partial oxidation should be used for such fuels.

Two reaction mechanisms have been proposed: one is the "direct mechanism" in which $\mathrm{CH}_{4}$ and $\mathrm{O}_{2}$ react on the adsorbed state on the catalyst surface to yield $\mathrm{CO}$ and $\mathrm{H}_{2}$ (Equation 3); the second one is the so-called "combustion-reforming mechanism". In this latter mechanism, $\mathrm{CH}_{4}$ and $\mathrm{O}_{2}$ first form $\mathrm{H}_{2} \mathrm{O}$ and $\mathrm{CO}_{2}$ (Equation 4), and then dry (Equation 5) and steam reforming (Equation 1) reactions producing $\mathrm{CO}$ and $\mathrm{H}_{2}$.

$$
\begin{array}{cc}
\mathrm{CH}_{4}+\mathrm{H}_{2} \mathrm{O} \leftrightarrow \mathrm{CO}+3 \mathrm{H}_{2} & \Delta \mathrm{H}_{298}^{\circ}=206.1 \mathrm{~kJ} \cdot \mathrm{mol}^{-1} \\
\mathrm{CO}+\mathrm{H}_{2} \mathrm{O} \leftrightarrow \mathrm{CO}_{2}+\mathrm{H}_{2} & \Delta \mathrm{H}_{298}=-41.2 \mathrm{~kJ} \cdot \mathrm{mol}^{-1} \\
\mathrm{CH}_{4}+1 / 2 \mathrm{O}_{2} \rightarrow \mathrm{CO}+2 \mathrm{H}_{2} & \Delta \mathrm{H}_{298}=-36 \mathrm{~kJ} / \mathrm{mol} \\
\mathrm{CH}_{4}+2 \mathrm{O}_{2} \rightarrow \mathrm{CO}_{2}+2 \mathrm{H}_{2} \mathrm{O} & \Delta \mathrm{H}_{298}=-801 \mathrm{~kJ} \cdot \mathrm{mol}^{-1} \\
\mathrm{CH}_{4}+\mathrm{CO}_{2} \rightarrow 2 \mathrm{CO}+2 \mathrm{H}_{2} & \Delta \mathrm{H}_{298}=+247 \mathrm{~kJ} \cdot \mathrm{mol}^{-1}
\end{array}
$$

In addition to these reactions, other side reactions eventually occur. These include

$$
\mathrm{CH}_{4}+\mathrm{O}_{2} \rightarrow \mathrm{CO}_{2}+2 \mathrm{H}_{2}
$$

and the formation of solid carbon by the Boudouard reaction

$$
2 \mathrm{CO} \rightarrow \mathrm{C}+\mathrm{CO}_{2}
$$

\section{Innovated Catalytic Partial Oxidation}

\section{Chemical-Looping Reforming and Combustion}

Chemical-looping reforming is a novel process for partial oxidation of hydrocarbon fuel where oxygen is 


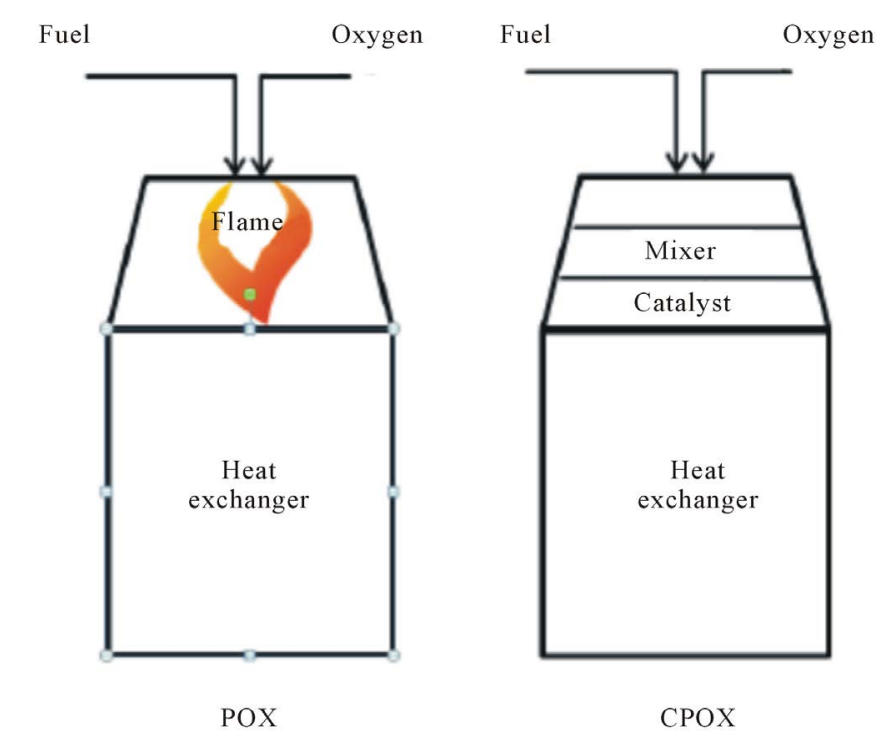

Figure 5. Reactor designs for POX and CPOX [12].

brought to the fuel by a solid oxygen carrier [20]. Chemical-looping reforming has been examined in a laboratory reactor consisting of two interconnected fluidized beds (Figure 6). Particles of $\mathrm{NiO}$ and $\mathrm{MgAl}_{2} \mathrm{O}_{4}$ were used as bed material, oxygen carrier and reformer catalyst. Natural gas was used as fuel. The reactor temperature was $820^{\circ} \mathrm{C}-930^{\circ} \mathrm{C}$. There was a continuous circulation of oxygen carrier particles between the fluidized-beds. In the fuel reactor the oxygen carrier was reduced by the fuel, which in turn was partially oxidized to $\mathrm{H}_{2}, \mathrm{CO}$, $\mathrm{CO}_{2}$ and $\mathrm{H}_{2} \mathrm{O}$. In the air reactor the oxygen carrier was re-oxidized with air. Formation of solid carbon was noticed for some cases. Addition of $25 \mathrm{vol} \%$ steam to the natural gas reduced the carbon formation substantially. $\mathrm{H}_{2}$ production by chemical-looping reforming with $\mathrm{CO}_{2}$ capture has also been examined in a process study, where it was found that an overall efficiency of $81 \%$ including $\mathrm{CO}_{2}$ sequestration is possible.

Figure 6 illustrates both chemical-loop reforming and combustion

$\mathrm{MeO}$ is the oxygen carrier in its oxidized form while $\mathrm{Me}$ is the reduced form.

Suitable oxygen carriers include metal oxides such as $\mathrm{Fe}_{2} \mathrm{O}_{3}, \mathrm{NiO}, \mathrm{CuO}$ and $\mathrm{Mn}_{3} \mathrm{O}_{4}$.

If the fuel is $\mathrm{CH}_{4}$, the oxygen carrier is $\mathrm{NiO}$ and the reactor temperature is $1200 \mathrm{~K}$, reaction (8) occurs in the air reactor.

$$
\text { Regeneration: } \mathrm{Ni}+1 / 2 \mathrm{O}_{2} \rightarrow \mathrm{NiO} \quad \Delta \mathrm{H}_{1200}=-234 \mathrm{~kJ} / \mathrm{mol}
$$

In the fuel reactor, reactions (equations 9, 10, 1 and 5) may occur, depending on the air ratio. Steam or $\mathrm{CO}_{2}$ could be added to the fuel to enhance the relative importance of reaction (1) or reaction (5) respectively. This could be used to adjust the $\mathrm{H}_{2} / \mathrm{CO}$ ratio in produced synthesis gas or to suppress formation of solid carbon in the fuel reactor. For chemical-looping combustion as much fuel as possible should be completely oxidized according to reaction (9).

$$
\begin{array}{ccc}
\text { Oxidation: } \mathrm{CH}_{4}+4 \mathrm{NiO} \rightarrow \mathrm{CO}_{2}+2 \mathrm{H}_{2} \mathrm{O}+4 \mathrm{Ni} & \Delta \mathrm{H}_{1200}=136 \mathrm{~kJ} / \mathrm{mol} \\
\text { Partial oxidation: } \mathrm{CH}_{4}+\mathrm{NiO} \rightarrow \mathrm{CO}+2 \mathrm{H}_{2}+\mathrm{Ni} & \Delta \mathrm{H}_{1200}=211 \mathrm{~kJ} / \mathrm{mol}
\end{array}
$$

Chemical-looping reforming is similar to chemical-looping combustion, but complete oxidation of the fuel is prevented by using low air to fuel ratio. Hence chemical-looping reforming can be described as a method for partial oxidation of hydrocarbon fuels that is utilizing chemical-looping as a source of oxygen. This is a considerable advantage compared to conventional technology since the need for expensive and power consuming air separation is eliminated.

The Short Contact Time-Catalytic Partial Oxidation (SCT-CPO) Technology

Precise knowledge of the mechanism of CPOX reaction is of vital importance because of the different thermal effects, which indeed affect both the design and heat management of industrial units [21]. 


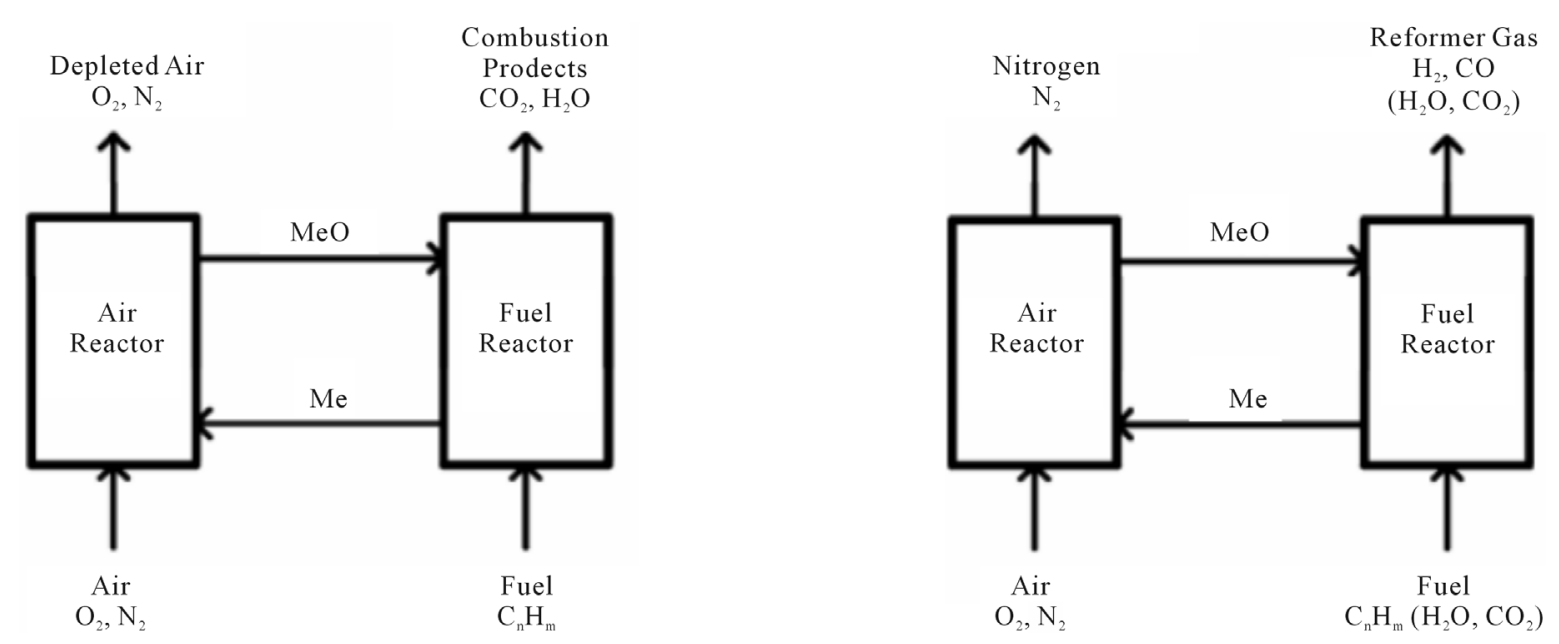

Figure 6. Schematic description of chemical-looping combustion (left) and chemical-looping reforming (right) [20].

Initial observation on the occurrence of short contact time hydrocarbon oxidation processes were reported in the years 1992-1993 [22]. These processes have been deeply studied since then, and the number of scientific articles published every year on this topic, is still high. Hickman and Schmidt [23] [24] demonstrated that near complete conversion of methane to mostly hydrogen and carbon monoxide could be achieved at reaction times as short as $1 \mathrm{~ms}$, promising dramatic reduction in a reactor size and complexity, as compared to existing syngas production technologies.

The fast and selective chemistry that is originated is confined inside a thin $(<1 \mathrm{~mm})$ solid-gas inter-phase zone surrounding the catalyst particles. Here, the molecules spend $10-6 \mathrm{~s}$ at temperatures variable between $600^{\circ} \mathrm{C}-1200^{\circ} \mathrm{C}$. A key issue for the technological exploitation is in the possibility of avoiding the propagation of reactions into the gas phase that has to remain at a "relatively low" temperature. This condition favors the formation of primary reaction products (namely $\mathrm{CO}$ and $\mathrm{H}_{2}$ ) inhibiting chain reactions. Indeed some experimental studies whose results have been partially described in literature [25]-[29] indicate that partial and total oxidation products are directly produced through parallel and competing surface reactions and that the formation of partial oxidation products is favored under SCT conditions due to the very high surface temperatures.

By proper choice of the operating conditions, surface temperatures are locally much higher than those predicted by thermodynamic equilibrium calculations assuming adiabatic reactors. The occurrence of the reactions in these local environments determines in some cases conversion and selectivity values higher than those predicted by the thermodynamic equilibrium at the reactor exit temperatures [30]. Moreover, the very high surface temperatures inhibit catalyst deactivation phenomena related to chemical poison effects [31] [32]. For these and other related reasons, this chemical process is carried out in very small reactors having a very high flexibility towards reactant flow variations. It has also been found that several hydrocarbon feed stocks, even containing sulfur and aromatic compounds can be fed to a SCT-CPO reactor for producing synthesis gas. Now a long term R\&D effort is approaching the industrialization phase of a technology whose main advantages concern are:

i) Small dimensions technical and operational simplicity.

ii) Possibility of modular construction of pre-fabricated and skid mounted units.

iii) Flexibility towards feedstock composition \& production capacity.

iv) Reduction of investment costs and energy consumption.

v) Reduction of $\mathrm{CO}_{2}$ production and possibility of an almost complete $\mathrm{CO}_{2}$ capture in case of $\mathrm{H}_{2}$ production plants.

Figure 7 illustrates the main characteristics of SCT-CPO technology application devoted to $\mathrm{H}_{2}$ production and $\mathrm{CO}_{2}$ removal [33].

\subsection{Auto-Thermal Reforming}

Like other reforming processes of methane, the purpose of the auto-thermal reforming is the production of syngas. Although auto-thermal reforming is an old idea, to date there are only a few commercial sites. The $\mathrm{H}_{2} / \mathrm{CO}$ 


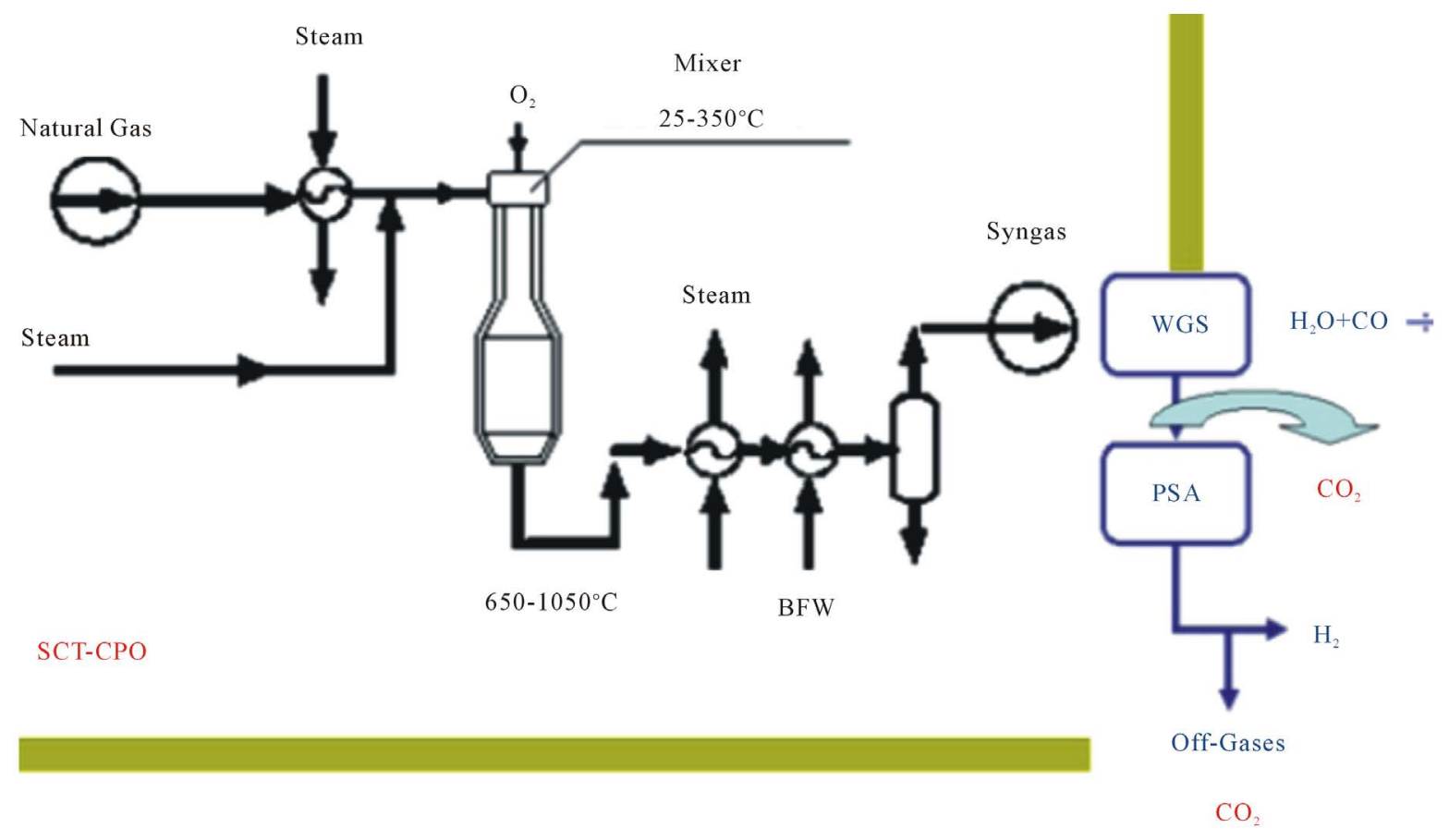

Figure 7. Main characteristics of SCT-CPO technology application devoted to $\mathrm{H}_{2}$ production and $\mathrm{CO}_{2}$ removal [33].

ratio of the syngas obtained in the auto-thermal reforming is a function of the gaseous reactant fractions introduced in the process input. Thus, the $\mathrm{H}_{2} / \mathrm{CO}$ ratio can be 1 or 2 [34]. Natural gas is mixed at high temperature with a mixture of oxygen and steam and ignited in a combustion chamber (see Figure 8) originating sub-stoichiometric flames that can be represented with both equations:

Reactions carried out in the Combustion zone $\approx 2200{ }^{\circ} \mathrm{K}$ are given by Equations (4) and (6), and those carried out in the reforming zone $1200-1400{ }^{\circ} \mathrm{K}$ are given by Equations (1) and (5).

By proper adjustment of oxygen to carbon and steam to carbon ratios, the partial combustion in the thermal zone supplies the heat for completing the subsequent endothermic steam and $\mathrm{CO}_{2}$ reforming reactions [36]. The product gas composition at the exit of the reactor results very close to the thermodynamic equilibrium of an adiabatic reactor, especially in large scale processes [37]. ATR is also utilized as a "secondary reformer" (for lowering the $\mathrm{CH}_{4}$ residue) and it is placed after a primary SMR in syngas plants integrated with Ammonia synthesis reactors. In this case the "secondary” ATR is fed with the syngas produced from SMR and Air.

\section{Innovation in Auto-Thermal Process}

\section{New Auto-Thermal Reactor (KBR)}

KBRATR reactor contains a combustion zone at the top and a catalyst filled bed at the bottom. The feedstock is mixed with a sub-stoichiometric amount of oxidant and burned in the combustion zone. There is an intermediate conical recirculation section (see Figure 9), where the hot gases continue to react, but are far from equilibrium. The resultant gases are passed over the catalyst in the bottom section to achieve as close to an equilibrium mixture as possible.

ATRs are attractive when used in combination with a reforming exchanger. They are also suited for making large volumes of synthesis gas, especially with hydrogen/carbon monoxide ratios such as 1.5/1 - 3/1. These ratios are desirable for synthesis of higher molecular weight hydrocarbons. ATRs have limited commercial experience. One belongs to SASOL in South Africa, which uses ATRs licensed by Lurgi out of Germany. KBR-designed ATRs have been installed in ammonia plants in Kitimat, Canada and Liaohe, China [38]. There are a handful of other ATRs installed in commercial operation.

\subsection{Dry Reforming}

Since $\mathrm{CO}_{2}$ is available in large quantities and at low costs, $\mathrm{CO}_{2}$ can be used in place of steam for reforming. 


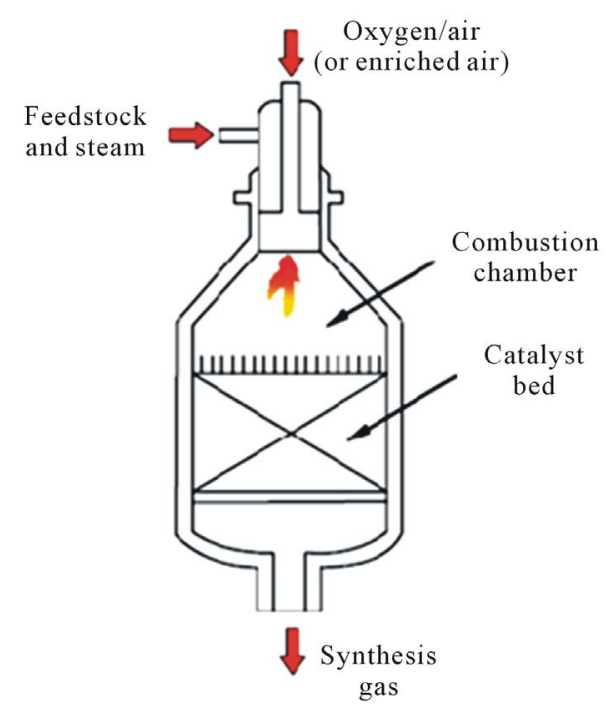

Figure 8. Diagram of an ATR reactor [35].

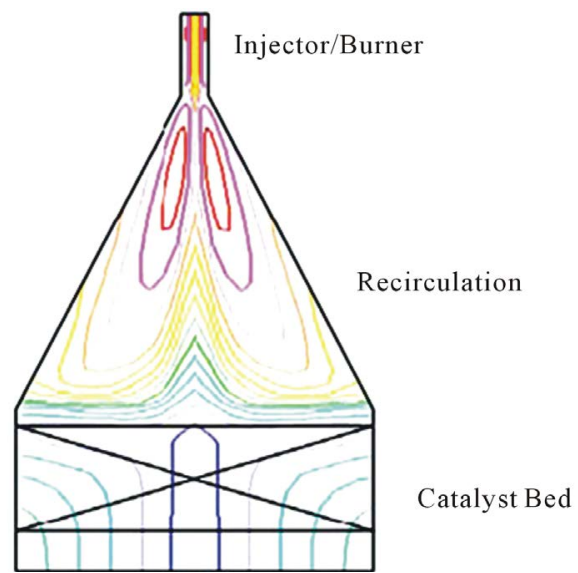

Figure 9. Schematic cross section of an ATR reactor vessel [38].

Therefore, the dry reforming which is reforming of methane with $\mathrm{CO}_{2}$ seems to be a promising technology for the production of syngas. Dry reforming of methane (DMR) is a process that uses waste carbon dioxide to produce syngas from natural gas. The synthesis gas produced by steam reforming has high $\mathrm{H}_{2} / \mathrm{CO}$ ratio which is not suitable for Fischer-Tropsch synthesis in the production of long chain higher hydrocarbons due to the excess hydrogen which suppresses chain growth and decreases the selectivity of higher hydrocarbons [39]. Conversely, methane reforming with $\mathrm{CO}_{2}$ plays an important role in the industries due to the production of syngas with a low $\mathrm{H}_{2} / \mathrm{CO}$ ratio $(\approx 1.0)$ which can be preferentially used for production of liquid hydrocarbons in Fischer-Tropsch synthesis network specifically those based on iron catalyst [40].

$$
\mathrm{CO}_{2}+\mathrm{H}_{2} \leftrightarrow \mathrm{CO}+\mathrm{H}_{2} \mathrm{O} \quad \text { RWGS } \quad \Delta \mathrm{H}_{298}^{\circ}=41 \mathrm{~kJ} / \mathrm{mol}
$$

Dry reforming reaction (Equation (5)) is slightly more endothermic than steam reforming. It is favored by low pressure and high temperature [41]. The presence of $\mathrm{CO}_{2}$ gives rise to more chances of carbon formation on catalyst surface due to production of $\mathrm{CO}$ and consumption of $\mathrm{H}_{2}$ via RWGS reaction Equation 11.

The dry reforming of methane with $\mathrm{CO}_{2}$ has received special attention in recent years due to two main reasons:

i) It produces syngas with a $\mathrm{H}_{2}$ : CO molar ratio that is suitable for products including F-T fuels and DME.

ii) The reaction consumes two types of greenhouse gases, $\mathrm{CO}_{2}$ and $\mathrm{CH}_{4}$ [42] [43]. 
The main disadvantage of dry reforming of methane is the significant deposition of carbon on the surface of the catalyst, which contributes to the reduction of its useful life. The main challenge for the industrial application of the reforming of methane with $\mathrm{CO}_{2}$ is related to the development of active catalytic materials, but with a very low coke formation rate, either on the catalysts or in the cold zones of the reactor. The carbon formation in this process can be controlled by using a support that favors the dissociation reaction of $\mathrm{CO}_{2}$ into $\mathrm{CO}$ and $\mathrm{O}$, the last species being the responsible for the cleaning of the metallic surface [44].

\subsection{Combined Methane Reforming}

\subsubsection{Steam and Dry Reforming}

A few studies have been reported on simultaneous steam and dry reforming of methane Equation (12) [45]-[48]. Combined steam and $\mathrm{CO}_{2}$ reforming of $\mathrm{CH}_{4}$ has attracted interest from both industrial and environmental perspectives. Firstly, from an environmental point view, the two most abundant carbon containing greenhouse gases, methane and carbon dioxide, can be utilized effectively in this reaction and converted into useful chemical products. This is an important area of recent catalytic research. Secondly, from an industrial perspective, the reaction produces syngas $\left(\mathrm{H}_{2} / \mathrm{CO}\right)$ with a ratio about 2, which is suitable for Fischere-Tropsch and methanol synthesis.

$$
\mathrm{CH}_{4}+1 / 3 \mathrm{CO}_{2}+2 / 3 \mathrm{H}_{2} \mathrm{O} \rightarrow 4 / 3 \mathrm{CO}+8 / 3 \mathrm{H}_{2} \quad \Delta \mathrm{H}^{\circ}{ }_{298 K}=+219 \mathrm{~kJ} / \mathrm{mol}
$$

The current technology for syngas production requires an oxygen plant for partial oxidation (equation 3); whereas the proposed technology utilizes $\mathrm{CO}_{2}$ using small installation (process intensification) and thus reducing operating and capital cost [49].

\section{Process Overview}

Figure 10 shows the simultaneous steam and $\mathrm{CO}_{2}$ reforming process of methane to syngas. In this process, the syngas generated by steam reforming is transferred to a heat exchanger, where the syngas is cooled and passed through a $\mathrm{CO}_{2}$ membrane separator. The $\mathrm{CO}_{2}$ membrane separates $\mathrm{CO}_{2}$ from the syngas mixture which initially contains $\mathrm{CO}, \mathrm{H}_{2}, \mathrm{CO}_{2}, \mathrm{H}_{2} \mathrm{O}$ and un-reacted $\mathrm{CH}_{4}$. The $\mathrm{CO}_{2}$-free syngas is sent to a two phase flash drum, where water is separated from syngas. The separated $\mathrm{CO}_{2}$ is sent to the dry reformer where the methane reacts with $\mathrm{CO}_{2}$ for increased production of syngas.

\subsubsection{Combined Dry and Partial Oxidation Reforming}

Combination of $\mathrm{CO}_{2}$ reforming and partial oxidation of methane (Equations (3) and (5)) to produce syngas with different precursors

Catalytic dry reforming process is highly endothermic and hence, high energy consumption. Catalytic partial oxidation is an exothermic reaction, so it tends to form hot spots in catalyst beds. It is difficult to control, particularly in a large scale operation. The process of combination of $\mathrm{CO}_{2}$ reforming and partial oxidation of methane (CDPOX) to produce syngas couples the advantages of DMR and POX and offsets the disadvantages of them, simultaneously [51]. Compared to POX and DMR, CDPOX is a green process and has the following advantages:

1) Energy coupling, 2) Controllable product ratio of $\mathrm{H}_{2} / \mathrm{CO}$ according to the need of the post-process, and 3) A safer operating environment.

Múnera and co workers [52] studied the best oxygen concentrations (3\% - 10\%) in CDPOX reforming using $\mathrm{Rh}(0.6) / \mathrm{La}_{2} \mathrm{O}_{3}$ as catalyst. They found that increasing the $\mathrm{O}_{2}$ content enhanced the $\mathrm{CH}_{4}$ conversion and at the same time drastically reduced the $\mathrm{CO}_{2}$ conversion; the best results were obtained with $10 \% \mathrm{O}_{2}$, which corresponds to a $\mathrm{CH}_{4} / \mathrm{O}_{2}$ ratio of 3.3 .

\subsection{Reforming Using Membrane}

\subsubsection{Oxygen Membrane}

Membrane reactors are non-porous multi component oxides suited to work at temperatures above $1000 \mathrm{~K}$ and have high oxygen flux and selectivity. These membranes are known as ion transport membranes (ITM).

In membrane reactors, the oxygen required to perform the CPO reaction is separated from air fed to one side of the membrane at temperatures around $300 \mathrm{~K}$ and moderate pressure (0.03 - $0.20 \mathrm{bar}$ ) and reacts on the other side with methane and steam at higher pressure (3 - 20 bar) to form a mixture of $\mathrm{CO}$ and $\mathrm{H}_{2}$. Then this mixture 


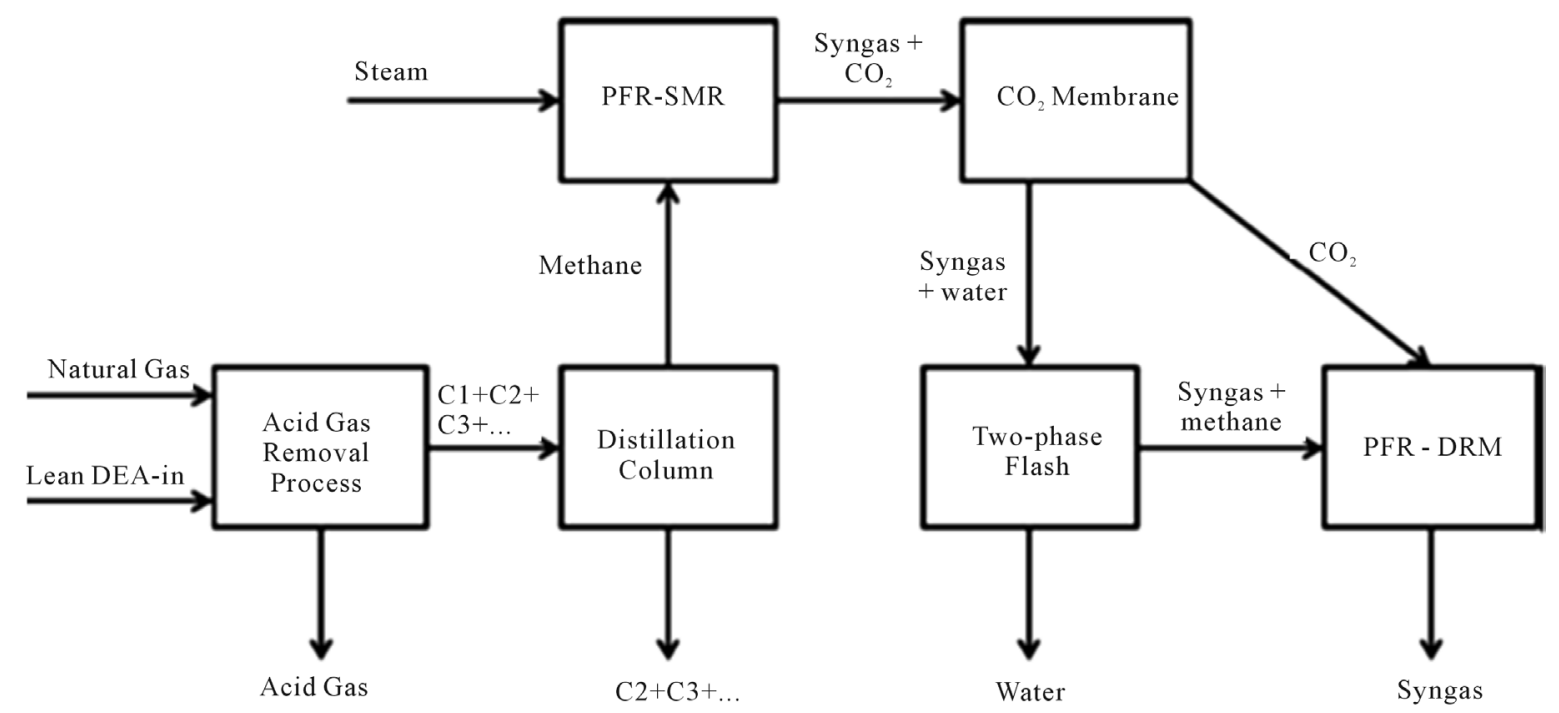

Figure 10. Schematic diagram of combined steam and dry reforming of methane [50].

can be processed downstream to produce $\mathrm{H}_{2}$ or liquid fuels. The concept of the membrane reactor is depicted in Figure 11 [21]. Among the different geometries employed for the ITM reactor, the flat plate system offers some advantages because it reduces the number of seals and thus makes safer operation. Among the ITM systems, perovskite structures remain prominent as they allow safe operation [53].

\subsubsection{Hydrogen Membrane}

Dense membranes are permeable to atomic or ionic forms of hydrogen. Pd-Pd alloy membranes offer high permeability only for hydrogen whereas zirconia and perovskites are highly selective only for oxygen. A schematic diagram of a tubular membrane reactor is presented in Figure 12. The catalytic membrane reactor is a cylindrical reactor equipped with a membrane. This membrane is inert with respect to chemical reaction and tubular in shape. The tubular membrane divides the reactor in two zones. The first zone is the shell side zone which a reaction zone is packed with catalyst particles. The reaction occurs in this zone. Second is tube side zone, also called permeate zone where the sweep gas is introduced co-currently with respect to feed to carry away the permeated gases from the permeate zone.

According to the low of mass action, and for reversible reactions, removal of one of the reaction products shifts the reaction to the RHS of the reaction equation. Therefore, removal of hydrogen from the reaction products DMR or SMR prevents the reversible reaction in Equations 5 and 1 as well as the RWGSR Equation 11, thus, increases conversion beyond the equilibrium conversion.

Membrane reactors for methane reforming reactions can be categorized according to the type of hydrogen separation membranes and the configuration of reactors and membranes. Dense metal membranes such as palladium and silver-palladium, which show complete perm selectivity toward hydrogen, have been used in hydrogen separation membranes for SMR reactions [55]. However, there are several problems with industrial applications of the dense membranes, including instability against acidic gases such as hydrogen sulfide $\left(\mathrm{H}_{2} \mathrm{~S}\right)$, high cost, adsorption of carbon monoxide that decreases hydrogen permeation, and formation of carbon alloys during SMR reactions [56]. Silica is another attractive material for hydrogen-selective membranes because of its amorphous structure in which the silica network allows the permeation of small molecules such as hydrogen. Recently, major progress in the preparation of porous membranes has made silica an alternative for use in hydrogen separation membranes for SMR. This has been achieved by either (CVD) chemical vapor deposition [57] or sol-gel processing [58], although the instability of silica in steam has been noted. Kanezashiand co workers [59] [60] succeeded in preparing hydrothermally stable silica membranes by doping metals such as $\mathrm{Ni}$ and $\mathrm{Co}$ into a $\mathrm{SiO}_{2}$ matrix by sol-gel processing. A catalytic membrane having both catalytic activity and separation ability has attracted increased attention because it has a more compact configuration than other types of membrane reactors. One need with catalytic membranes is enhancement of catalytic activity, since only a limited amount of catalysts can be impregnated inside catalytic membranes [58]. 


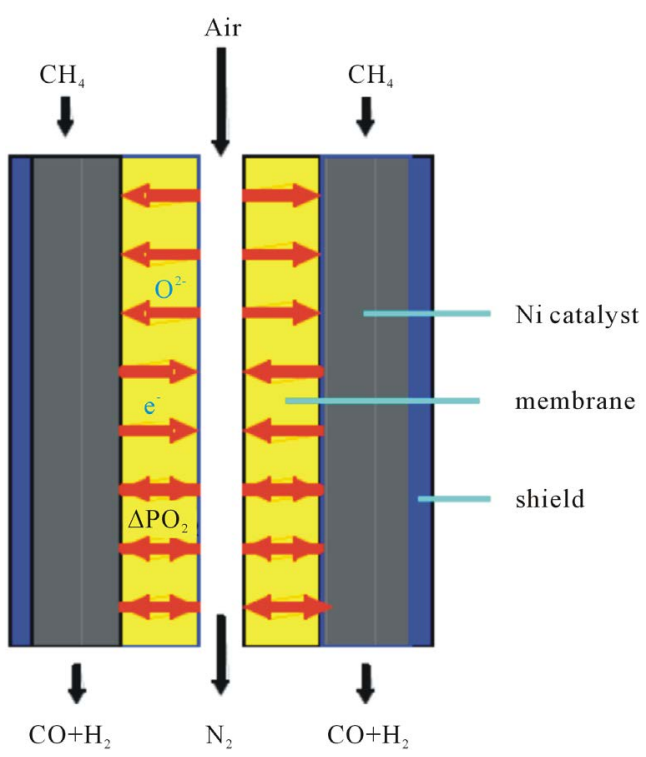

Figure 11. Sketch diagram showing the principle of oxygen membrane reforming [21].

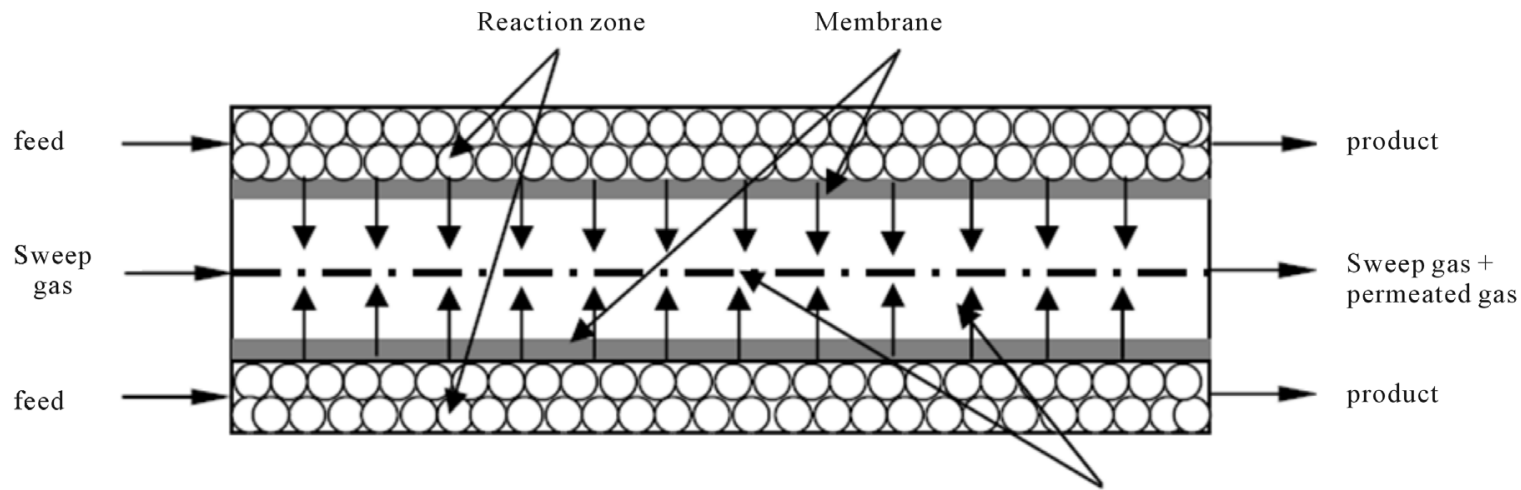

Permeation zone

Figure 12. Schematic diagram of a tubular membrane reactor [54].

A novel Multi-Channel Membrane Reactor (MCMR) was designed and built for the small-scale production of hydrogen via Steam Methane Reforming (SMR) [61]. The developed MCMR consists of alternate channels for catalytic SMR and Methane Catalytic Combustion (MCC) which provide the heat of reaction needed by the endothermic reforming reaction. A palladium-silver membrane inside the reforming gas channel shifts the reaction equilibrium, allowing lower operating temperatures, and producing pure hydrogen in a single vessel. Results showed that methane conversion reached $91 \%$ and a hydrogen purity in excess of $99.99 \%$ at $570{ }^{\circ} \mathrm{C}$ and 15 bar.

Linde Engineering [6] developed a new small-scale reformer process based on palladium membrane tubes that can produce pure hydrogen without a separate purification unit. The composite palladium membranes comprise a porous metal support, a ceramic diffusion barrier layer and the final selective, thin and defect-free palladium layer. The chemical equilibrium of the reforming reaction shifts towards the products and the whole process can be operated at lower temperatures of $600^{\circ} \mathrm{C}-650^{\circ} \mathrm{C}$ while delivering higher conversion rates.

\subsection{Tri-Reforming (TMR)}

It is a new process designed for the direct production of synthesis gas with desirable $\mathrm{H}_{2} / \mathrm{CO}$ ratios by reforming methane or natural gas using flue gas from fossil fuel based electric power plants without pre-separation of $\mathrm{CO}_{2}$. These flue gases are regarded as major source of $\mathrm{CO}_{2}$ emission in the U.S. Generally the compositions of flue gases depend on the types of fossil fuels used in power plants. Flue gases from natural gas-fired power plants 
typically contain:

$8 \%-10 \% \mathrm{CO}_{2}, 18 \%-20 \% \mathrm{H}_{2} \mathrm{O}, 2 \%-3 \% \mathrm{O}_{2}$, and $67 \%-72 \% \mathrm{~N}_{2}$;

Flue gases from coal-fired boilers primarily contain:

$12 \%-14 \% \mathrm{CO}_{2}, 8 \%-10 \% \mathrm{H}_{2} \mathrm{O}, 3 \%-5 \% \mathrm{O}_{2}, 72 \%-77 \% \mathrm{~N}_{2}$, and trace amount of $\mathrm{NO}_{\mathrm{x}}, \mathrm{SO}_{\mathrm{x}}$, and particulates [62].

It is hypothesized that tri-reforming be a synergetic combination of $\mathrm{CO}_{2}$ reforming (Equation 5), steam reforming (Equation 1) and methane oxidation reactions (Equation 3 and Equation 4). Therefore, tri-reforming is expected to encompass a number of unique features. One major feature is its ability to convert $\mathrm{CO}_{2}$ in flue gas without $\mathrm{CO}_{2}$ separation while avoiding the use of pure $\mathrm{CO}_{2}$ and the severe problem of carbon deposition encountered in $\mathrm{CO}_{2}$ reforming system [63]-[67]. Currently most of pure $\mathrm{CO}_{2}$ is obtained from $\mathrm{CO}_{2}$ separation processes (e.g. absorption, adsorption, and membrane separation) that are often energy-intensive and costly. Some separation processes could lower the power plant energy output as much as $20 \%$ [68].

Other features of tri-reforming include that there is no need to handle pure oxygen and it directly produces synthesis gas with a desirable $\mathrm{H}_{2} / \mathrm{CO}$ ratio (e.g. $\mathrm{H}_{2} / \mathrm{CO}=1.5$ - 2). Furthermore, oxygen in flue gas may help to ease the reaction energy requirement as encountered in $\mathrm{CO}_{2}$ reforming alone or steam reforming alone. In general, the new tri-reforming process concept is consistent with the goals of DOE Vision 21 for power plants with respect to decreasing green house gas emission, improving power generation efficiency and co-producing fuels and chemicals [69].

It should be pointed out that the $\mathrm{H}_{2} / \mathrm{CO}$ ratio in synthesis gas is important since synthesis gas with different $\mathrm{H}_{2} / \mathrm{CO}$ ratios has different applications in industry. The current major application of synthesis gas (not hydrogen) includes methanol synthesis and Fischer-Tropsch (F-T) synthesis that require synthesis gas with a $\mathrm{H}_{2} / \mathrm{CO}$ ratio close to 2. However, synthesis gas directly produced from $\mathrm{CO}_{2}$ reforming of methane has $\mathrm{H}_{2} / \mathrm{CO}$ ratio close to 1 . Hence, this kind of synthesis gas $\left(\mathrm{H}_{2} / \mathrm{CO}\right.$ ratio $\left.\leq 1\right)$ requires further treatment in order to be applied in methanol and F-T synthesis.

Similarly synthesis gas produced from steam reforming cannot be directly applied in methanol or F-T synthesis either since the $\mathrm{H}_{2} / \mathrm{CO}$ ratio of synthesis gas produced from steam reforming is usually larger than 3 . Although methane partial oxidation produces synthesis gas with a $\mathrm{H}_{2} / \mathrm{CO}$ ratio of 2 , methane partial oxidation is difficult to control due to its exothermic feature and is dangerous and expensive due to the handling of pure oxygen. Tri-reforming, however, is expected to readily produce synthesis gas with the desired $\mathrm{H}_{2} / \mathrm{CO}$ ratios of $1.5 \sim 2$ by manipulating tri-reforming reactant compositions under relatively mild reaction conditions.

The concept of tri-reforming using power plant flue gas was first proposed by [62] [70]. Before 1999, several papers were published on the study of combined $\mathrm{CO}_{2}$ reforming and partial oxidation reaction [71]-[73] and simultaneous steam and $\mathrm{CO}_{2}$ reforming of methane in the presence of oxygen [74]. The results in these papers have indicated that combined reforming is feasible. However, the new tri-reforming process still faces a number of challenges. The future challenges include, for example, effective conversion of $\mathrm{CO}_{2}$ in the presence of $\mathrm{O}_{2}$ and $\mathrm{H}_{2} \mathrm{O}$; the heat management; the minimization of the effect of SOx and NOx in flue gas on tri-reforming process; the management of inert gas $\mathrm{N}_{2}$ in flue gas; and the integration of new process into power plants.

Tri reforming can also be used for converting and utilizing $\mathrm{CO}_{2}$-rich natural gas [75] as some natural gas resources contain up to $50 \mathrm{vol} \% \mathrm{CO}_{2}$ which are not yet utilized commercially due to the high $\mathrm{CO}_{2}$ concentration. Tri-reforming process concept was recently proposed and developed at the Pennsylvania State University [62] [75], and by independent studies on tri-reforming catalysts [76]-[79].

Figure 13 depicts the process concept.

\subsection{Comparison between the Different Methods for Reforming of Methane}

Steam reforming is the main reforming process of methane that is predominantly utilized because it has the greatest value for $\mathrm{H}_{2} / \mathrm{CO}$ ratio, i.e., the product of the reforming process is a gas flow considered ideal for the development of the catalytic process of obtaining a gas hydrogen flow of high purity. However, as the process of steam reforming is considered too expensive, the other types of catalytic chemical processes are considered as alternative processes for carrying out the reforming of methane and they were developed with the aim of making savings in thermal energy consumption required for the catalytic process to occur. The choice of process type to reforming of methane must take into consideration the economic viability of the process related to the destination to be given to the syngas produced. 


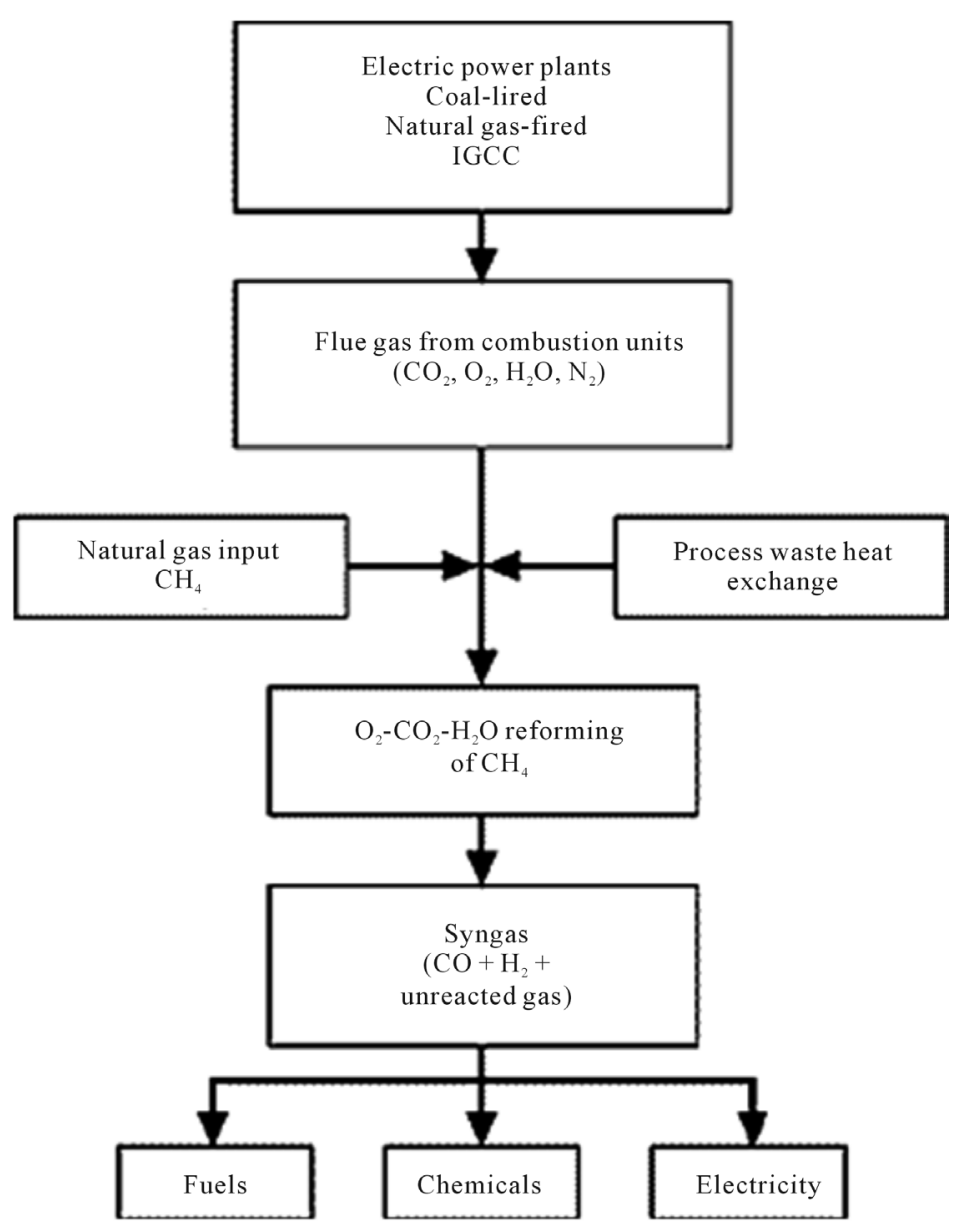

Figure 13. Process concept for tri-reforming of natural gas using flue gas from fossil fuel based power plants [62].

Partial oxidation and auto-thermal reforming are good choices to produce syngas when the value of $\mathrm{H}_{2} / \mathrm{CO}$ ratio is adequate and especially when it comes to reduce the consumption of thermal energy, a most important factor. In short, it can be said that the selection of the type of catalytic chemical process of reforming of methane depends on the type of application of the syngas produced. A comparison of syngas generation technologies using natural gas as feed is shown in Table 1.

\section{Catalysis}

Generally, the catalysts used for the reforming reactions are categorized into two groups:

- Supported noble metals, and

- Non-noble transition metals.

Several investigations have been conducted to find the most suitable catalyst for the production of syngas using different processes. There has been extensive research work on steam reforming, catalytic partial oxidation and dry reforming catalysts including rhodium [80]-[82], ruthenium [83]-[85] and platinum [86]-[88], Palladium [89], Iridium [90] catalysts. Studies have proved that nickel based catalysts supported with metal oxides give the best conversion rate of methane [91]. Although noble metals-based catalysts are more active and usually less prone to deactivation by carbon formation or oxidation, owing to their low cost (100 - 150 times less expensive than noble metals [92]), nickel based catalysts are more widely used in industrial applications. However, their stability is poor due to carbon deposition. Therefore, the inhibition of carbon deposition for non-noble metal catalysts became the most important topic for reforming of methane especially in dry reforming. The strategies, which were exploited to inhibit carbon deposition, are to control particle sizes of active components and to in- 
crease the surface basicity of catalysts. Several approaches were developed to control the metal particle sizes, including the enhancement of metal-support interaction, the formation of solid solutions, and plasma-treatments. To increase the surface basicity of catalysts, basic metal oxides were employed as support or promoter. Several authors have resulted in improved catalysts and processes, leading to improved overall efficiency and environmental performance [93] [94]. In general, we can say that the group VIII (except Osmium) metals are highly active in the reforming reaction, each of them showing their own characteristics.

The effect of the support has also been investigated in other active metals, and the tendencies are not the same in all cases. Bitter et al. [95] found that the trend in stability on supported platinum was $\mathrm{ZrO}_{2}>\mathrm{TiO}_{2}>\mathrm{Al}_{2} \mathrm{O}_{3}$. This trend was different in supported nickel, $\mathrm{Al}_{2} \mathrm{O}_{3}$ supported nickel being more stable than the corresponding $\mathrm{TiO}_{2}$ supported catalyst [96]. It has been reported that $\mathrm{Pt} / \mathrm{Ce}_{\mathrm{x}} \mathrm{Zr}_{1-\mathrm{x}} \mathrm{O}_{2}$ catalysts are more active, stable and selective than the $\mathrm{CeO}_{2}$ and $\mathrm{ZrO}_{2}$ supported counter parts. The higher reducibility and oxygen storage/release capacity of $\mathrm{Pt} / \mathrm{Ce}_{\mathrm{x}} \mathrm{Zr}_{1-\mathrm{x}} \mathrm{O}_{2}$ catalysts promotes the continuous removal of carbonaceous deposits from the active sites, which takes place at the metal-support interfacial perimeter [97].

\subsection{Promoters}

Zirconia [98], lanthana [99] [100], ceria [101] and ceria-zirconia [102] [103] oxides have been recently reported as promoters of methane reforming reactions. Incorporation of a $5 \mathrm{wt} \% \mathrm{ZrO}_{2}$ to a base $\mathrm{Ni} / \mathrm{SiO}_{2}$ catalyst resulted in excellent performance for the CPOX reaction $\mathrm{O}_{2}$ mixture in a fluidized-bed reactor. Chawla et al. [104] prepared Nickel catalyst by impregnation method using support- $\mathrm{Al}_{2} \mathrm{O}_{3}$ and different types of promoters to improve activity, stability and selectivity in order to reduce coke formation and to achieve long-term operation. Nickel catalysts promoted by the $\mathrm{ZrO}_{2}$ shows higher dispersion of the metal particle on the surface of the support than the un-promoted catalysts [105]. It has been found that the $\mathrm{ZrO}_{2}, \mathrm{CeO}_{2}, \mathrm{~K}_{2} \mathrm{O}$ and $\mathrm{MgO}$ promoted $10 \% \mathrm{Ni} /-\mathrm{Al}_{2} \mathrm{O}_{3}$ catalysts exhibited good activity, stability and long-term operation as compared to the un-promoted catalysts.

Iron has also been used as a promoter. Park et al. [106] prepared a set of mesoporous nickel-iron-alumina xerogel catalysts with different iron loadings. The catalyst formula " $20 \mathrm{Ni}_{4} \mathrm{FeAl}$ " reviled the finest nickel dispersion, the highest nickel surface area and the best catalytic performance in the steam reforming of LNG.

\subsection{Perovskite Precursors}

Perovskite oxides have also been extensively used as precursors of supported metal catalysts. Perovskites are mixed oxides with a general stoichiometry of $\mathrm{ABO}_{3}$, where $\mathrm{A}$ and $\mathrm{B}$ can be partially substituted by other metals.

Table 1. Comparison of syngas generation technologies with natural gas feed [5].

\begin{tabular}{|c|c|c|c|}
\hline Technology & Advantages & Disadvantages & Developers/Licensors \\
\hline POX & Feed stock desulfurization not required & $\begin{array}{l}\text { Very high process operating temperature } \\
\text { Usually requires oxygen plant }\end{array}$ & $\begin{array}{l}\text { Texaco Inc. and Royal } \\
\text { Dutch/Shell }\end{array}$ \\
\hline SMR & $\begin{array}{l}\text { Most extensive industrial experience } \\
\text { Oxygen not required, lowest process operating } \\
\text { temperature } \\
\text { Best } \mathrm{H}_{2} / \mathrm{CO} \text { ratio for production of liquid fuels. }\end{array}$ & $\begin{array}{l}\text { Highest air emissions More costly than } \\
\text { POX and auto-thermal reformers } \\
\text { Recycling of CO and removal of the } \\
\text { excess hydrogen by means of membranes }\end{array}$ & $\begin{array}{l}\text { Haldor Topsoe AS, Foster } \\
\text { Wheeler Corp, Lurgi AG, } \\
\text { International BV, Kinetics } \\
\text { Technology and Uhde GmbH }\end{array}$ \\
\hline ATR & $\begin{array}{l}\text { Lowest process temperature requirement than } \\
\text { POX. Syngas methane content can be tailored } \\
\text { by adjusting reformer outlet temperature }\end{array}$ & $\begin{array}{l}\text { Limited commercial experience } \\
\text { Usually requires oxygen plant }\end{array}$ & Lurgi, Haldor Topsoe \\
\hline DMR & $\begin{array}{l}\text { Green house gas } \mathrm{CO}_{2} \text { can be consumed instead } \\
\text { of releasing into atmosphere Almost } 100 \% \text { of } \\
\mathrm{CO}_{2} \text { conversion }\end{array}$ & $\begin{array}{l}\text { Formation of coke on catalyst. } \\
\text { Additional heat is required as the } \\
\text { reaction takes place at } 873 \mathrm{~K}\end{array}$ & Carbon Sciences \\
\hline CSDR & $\begin{array}{l}\text { Best } \mathrm{H}_{2} / \mathrm{CO} \text { ratio for production of liquid fuels } \\
\text { Coke deposition drastically reduced. }\end{array}$ & $\begin{array}{l}\text { Separation of un-reacted methane from } \\
\text { SMR syngas. Project installation cost. }\end{array}$ & Midrex Process \\
\hline TMR & $\begin{array}{l}\text { Directly using flue gases, rather than pre } \\
\text { separated and purified } \mathrm{CO}_{2} \text { from flue gases. } \\
\text { Over } 95 \% \text { of methane and } 80 \% \mathrm{CO}_{2} \text { conversion } \\
\text { can be achieved }\end{array}$ & $\begin{array}{l}\text { Usually requires oxygen plant. } \\
\text { Low } \mathrm{H}_{2} / \mathrm{CO} \text { ratio ratios limit its } \\
\text { large-scale application for F-T \& } \mathrm{MeOH} \\
\text { synthesis }\end{array}$ & $\begin{array}{l}\text { Haldor } \\
\text { Topsoe AS }\end{array}$ \\
\hline
\end{tabular}


Most of the perovskites studied have a lanthanide and/or alkaline earth metal in the A site, and the active metal in the B site. After reduction, a highly dispersed metal supported in the lanthanide or alkaline earth oxide is obtained [107]

Perovskite structures of the type $\mathrm{CaTiO}_{3}, \mathrm{SrTiO}_{3}, \mathrm{BaTiO}_{3}$ and $\mathrm{LaAlO}_{3}$ have been used as supports by [108] to prepare supported nickel catalysts. All these supported $\mathrm{Ni}$ catalysts showed better performance than $\mathrm{Ni} / \mathrm{Al}_{2} \mathrm{O}_{3}$ reference catalyst. Specifically, the $\mathrm{Ni} / \mathrm{LaAlO}_{3}$ was the most active catalyst which suppressed the hot spot formation at the catalyst inlet. It has been shown that the $\mathrm{LaNiO}_{3}$ perovskite renders small $\mathrm{Ni}$ particles deposited on a $\mathrm{La}_{2} \mathrm{O}_{3}$ substrate upon reduction. The resulting catalyst exhibited over $90 \% \mathrm{CH}_{4}$ conversion at $800^{\circ} \mathrm{C}$ with $\mathrm{H}_{2}$ and $\mathrm{CO}$ production at a ratio close to 2:1 [109]. Traditional catalyst preparation methods involve the precipitation and/or impregnation techniques; the latter has broadly been used for the preparation of Ni-supported catalysts for different areas of catalysts preparation methods [110]. However, the conventional impregnation method does not provide adequate control over the final size, morphology and dispersion of active metal particles. In the literature several other preparation methods such as surfactant assisted route to reduce the particle size of the support material, sol-gel, mixed oxides solid solution micro emulation and combustion synthesis were investigated as alternatives to traditional methods [111].

\subsection{Nano Catalysts}

On conventional reforming catalysts, discrete metal nano crystals (typically $1.15 \mathrm{~nm}$ ) are dispersed on support particles that are one to several orders of magnitude larger than the supported metal nano particles. However, when the particle sizes of an oxide support are reduced to such an extent that they become comparable to that of the active metal particles, the oxide may deviate dramatically from its function as a conventional catalyst support. Such metal/oxide catalyst with size-comparable metal and oxide nano crystals may be better called a metal/oxide nano composite rather than an "oxide-supported" metal catalyst [112].

When the sizes of zirconia particles become smaller than $25 \mathrm{~nm}$, the oxide forms nano composite catalysts with size-comparable Ni-metal nano crystals $(10-15 \mathrm{~nm})$. The nano composite catalysts show extremely stable catalysis, which is in strong contrast with the deactivating Ni catalyst supported on bigger zirconia particles ( $>25$ $\mathrm{nm}$ ). Energy dispersive analysis of X-rays focused on individual particles showed little contamination between Ni-metal and zirconia nano crystals. This raises the possibility of tailoring the catalytic behavior of oxide-supported metal catalysts by reducing the particle size of oxide to make high performance nano composite catalysts [112].

The reason for high stability of nanoco mposite $\mathrm{Ni} / \mathrm{ZrO}_{2}$ remains unclear. It could be due to the enhancement of oxygen transfer ability of zirconia particles smaller than $25 \mathrm{~nm}$ or by formation of nano composite with high percentage of metal/oxide boundary or perimeter $\mathrm{CO}_{2}$, which in turn increase oxidative removal of carbon atoms to produce CO [112].

Application of the MgO nanocrystals for support of nickel catalyst was also successful and gave promising results for highly active as well as very stable $\mathrm{Ni} / \mathrm{MgO}$ catalysts for the dry reforming of methane [113]. The work of Ruckenstein and $\mathrm{Hu}$, [96] showed that $\mathrm{NiO} / \mathrm{MgO}$ catalysts prepared by impregnation of nickel nitrate onto MgO powders containing 7 - $10 \mathrm{~nm}$ nano crystals developed stable activities for the reforming reaction after reduction at $1063 \mathrm{~K}$.

Mesoporous materials when used as the support could control the size of nano particles by the diameter of their pores [111] [114]. It has been found that appropriately prepared mesoporous, nano crystalline pure tetragonal zirconia could result in an active and stable nickel based catalyst for dry reforming reaction [115]. Under relatively low temperatures and low carbon dioxide to methane ratios which thermodynamically favors coke formation, long-term stable performance was observed over $5 \% \mathrm{Ni}$ catalyst. The addition of $\mathrm{CeO}_{2}$ to the support was found to increase the surface area of the resulting zirconia powder [116]. The use of alkaline promoter [117] as well as $\mathrm{CeO}_{2}$ and $\mathrm{La}_{2} \mathrm{O}_{3}$ [118] further improved the stability and activity of the resulting catalysts under conditions otherwise coke formation is extensive.

\subsection{Innovated Multi Component Thermo-Neutral Reaction (TNR) Catalyst}

Most recently, an innovative steam- and/or $\mathrm{CO}_{2}$-reforming designated as Thermo-Neutral Reforming (TNR) has been introduced by [119] after several years studies on ultra-rapid catalytic reactions. The reformer can be reduced two-order magnitude compared with traditional steam reformers, because the large endothermic heat of 
reforming is compensated by the large exothermic heat of complete combustion on the same catalyst surface without supply of heat from outside of the reactor.

By applying the extremely compact size of the TNR system to the successive syngas converters packed newly developed catalysts, highly effective ultra clean fuels such as $\mathrm{MeOH}$, DME, and sulfur-free \& non-aromatic high octane number gasoline can be produced effectively with non-expensive costs.

Recent advances in the steam reforming catalyst have been done through the $\mathrm{CO}_{2}$ reforming associated with the $\mathrm{CO}_{2}$ mitigation against the global warming crisis [119]. The common sense of the steam reforming has been that the excess steam is necessary to prevent coke formation by the reaction between deposited carbon and steam to convert to carbon mono oxide and hydrogen, while in case of dry reforming with $\mathrm{CO}_{2}$ there is no opportunity to avoid coke formation. Inui [120] investigated a novel catalyst to avoid coke formation even under the reaction condition of $\mathrm{CO}_{2}$ reforming. As criteria to develop this ideal catalyst; the following performances have been required:

- No coke formation,

- High sulfur tolerance,

- Ultra-rapid reaction rate,

- High-temperature resistance,

- Low temperature start-up in a very short time,

- Non toxic, and

- Low production cost.

This novel catalyst has both catalytic functions of combustion and steam reforming for hydrocarbons, the thermo-neutral reactions (TNR) on the same catalyst surface could be realized [120]. As the result, the reactor size could be reduced to two-orders of magnitude that of traditional hydrocarbon steams reforming (HSR) method [121]. Catalyst composition of the four-component catalyst (wt\%): $10 \mathrm{Ni}-6.0 \mathrm{Ce}_{2} \mathrm{O}_{3}-1.0 \mathrm{Pt}-0.2 \mathrm{Rh}$. The synergistic effect of the four-component catalyst on $\mathrm{CO}_{2}$ reforming of methane is shown in Figure 14 [122].

\section{Conclusion}

From the above review we can conclude that each reforming method has its particularities and the preference of one method over another depends on the final application of the syngas produced. If we need maximum hydrogen production e.g. for the case of ammonia synthesis then steam reforming is the traditional choice. On the other hand, if the syngas produced is to be utilized in the production of liquid hydrocarbon fuels then ATR and POX or more recently SCT-CPO reforming would be the proper choice where $\mathrm{H}_{2} / \mathrm{CO}$ ratio can be adjusted to the required ratio. New comers like dry reforming and tri-reforming will certainly occupy their proper place with the increased climatic awareness where $\mathrm{CO}_{2}$ is utilized as a raw material. Nickel catalysts supported on alumina or silica are the most used catalysts in the reforming of methane because of their low cost compared to noble metals. It must be emphasized that the method of preparation affects the final structure of the catalyst and therefore its activity. Nano catalysts are gaining grounds in the reforming process. Future challenges include the development of better catalysts that have longer life time and enhance conversion at moderate operating

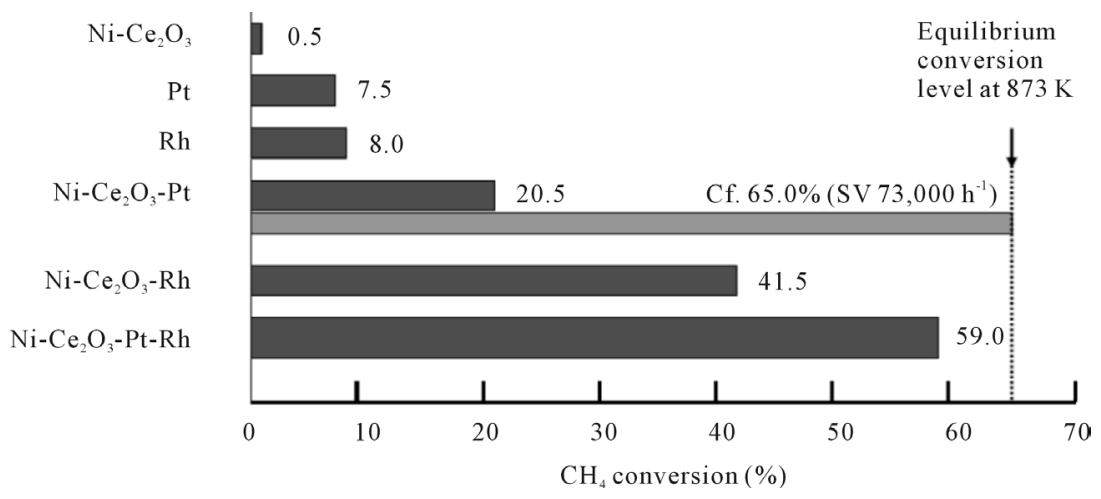

Figure 14. Comparison of the catalytic performance in $\mathrm{CO}_{2}$ reforming of methane for various catalyst components-Synergy appeared by proper combination of catalyst components [122]. 
conditions to reduce the operating cost as well as the development of more compact reactors (Process Intensification) e.g. membrane reactors to lower the capital cost.

\section{References}

[1] Budzianowski, W. (2013) Modeling of $\mathrm{CO}_{2}$ Content in the Atmosphere until 2300: Influence of Energy Intensity of Gross Domestic Product and Carbon Intensity of Energy. International Journal of Global Warming, 5, 1-17. http://dx.doi.org/10.1504/IJGW.2013.051468

[2] Mackenzie, F.T. and Mackenzie, J.A. (1995) Our Changing Planet. Prentice-Hall, Upper Saddle River.

[3] Spath, P.L. and Dayton, D.C. (2003) Preliminary Screening Technical and Economic Assessment of Synthesis Gas to Fuels and Chemicals with Emphasis on the Potential for Biomass Derived Syngas. National Renewable Energy Lab Golden Co., Golden. http://dx.doi.org/10.2172/1216404

[4] Park, C.S., Vo, C., Raju, A.S.K. and Norbeck, J.M. (2012) Work Authorization to Develop a White Paper on the Potential Application of Using the Seam Hydro Gasification Process to Convert Biomass Materials Prevalent in Southern California into Synthetic Fuels. University of California, Riverside.

[5] Samuel, P. (2003) GTL Technology Challenges and Opportunities in Catalysis. Bulletin of the Catalysis Society of India, 2, 82-99.

[6] Linde Company. http://www.linde-engineering.com

[7] Aasberg-Petersen, K., Dybkjær, I., Ovesen, C.V., Schjødt, N.C., Sehested, J. and Thomsen, S.G. (2011) Invited Review: Natural Gas to Synthesis Gas-Catalysts and Catalytic Processes. Journal of Natural Gas Science and Engineering, 3, 423-459. http://dx.doi.org/10.1016/j.jngse.2011.03.004

[8] Rafiq, M.H., Owrand, F. and Hustad, J.E. (2009) Synthesis Gas from Methane by Using Plasma-Assisted Gliding Arc Catalytic Partial Oxidation Reactor. 1st Trondheim Gas Technology Conference, Trondheim, Norway, 21-22 October 2009, 1667-1670.

[9] Neiva, L.S. and Gama, L. (2010) A Study on the Characteristics of the Reforming of Methane: A Review. Brazilian Journal of Petroleum and Gas, 4, 119-127. http://dx.doi.org/10.5419/bjpg2010-0013

[10] Liu, J.A. (2006) Kinetics, Catalysis and Mechanism of Methane Steam Reforming. Master Thesis of Science in Chemical Engineering, Worcester Polytechnic Institute, Worcester.

[11] Pena, M., Gomez, J. and Fierro, J.L.G. (1996) New Catalytic Routes for Syngas and Hydrogen Production. Applied Catalysis A: General, 144, 7-57. http://dx.doi.org/10.1016/0926-860X(96)00108-1

[12] Liu, K., Deluga, G.D., Bitsch-Larsen, A., Schmidt, L.D. and Zhang, L. (2010) Catalytic Partial Oxidation and Autothermal Reforming. In: Liu, K., Song, C. and Subramani, V., Eds., Hydrogen and Syngas Production and Purification Technologies, Wiley, New York, 127-155.

[13] York, A.P.E., Xiao, T. and Green, M.L.H. (2003) Brief Overview of the Partial Oxidation of Methane to Synthesis Gas. Topics in Catalysis, 22, 345-358. http://dx.doi.org/10.1023/A:1023552709642

[14] Mitri, A., Neumann, D., Liu, T. and Veser, G. (2004) Reverse-Flow Reactor Operation and Catalyst Deactivation during High-Temperature Catalytic Partial Oxidation. Chemical Engineering Science, 59, 5527-5534. http://dx.doi.org/10.1016/j.ces.2004.07.104

[15] Kolios, G., Frauhammer, J. and Eigenberger, G. (2000) Auto-Thermal Fixed Bed Reactor Concepts. Chemical Engineering Science, 55, 5945-5967. http://dx.doi.org/10.1016/S0009-2509(00)00183-4

[16] Neumann, D. and Veser, G. (2005) Catalytic Partial Oxidation of Methane in a Reverse-Flow Reactor. AIChE Journal, 51, 210-223. http://dx.doi.org/10.1002/aic.10284

[17] Enger, B.C., Lødeng, R. and Holmen, A. (2008) A Review of Catalytic Partial Oxidation of Methane to Synthesis Gas with Emphasis on Reaction Mechanisms over Transition Metal Catalysts. Applied Catalysis A: General, 346, 1-27. http://dx.doi.org/10.1016/j.apcata.2008.05.018

[18] Biesheuvel, P.M. and Kramer, G.J. (2003) Two-Section Reactor Model for Auto-Thermal Reforming of Methane to Synthesis Gas. AIChE Journal, 49, 1827-1837. http://dx.doi.org/10.1002/aic.690490719

[19] Schicks, J., Neumann, D., Specht, U. and Veser, G. (2003) Nano-Engineered Catalysts for High-Temperature Methane Partial Oxidation. Catalysis Today, 81, 287-296. http://dx.doi.org/10.1016/S0920-5861(03)00116-0

[20] Rydén, M., Lyngfelt, A. and Mattisson, T. (2006) Production of $\mathrm{H}_{2}$ and Synthesis Gas by Chemical-Looping Reforming. Presented at GHGT-8, Trondheim, Norway, 19-22 June 2006, 295.

[21] Al-Sayari, S.A. (2013) Recent Developments in the Partial Oxidation of Methane to Syngas. The Open Catalysis Journal, 6, 17-28. http://dx.doi.org/10.2174/1876214X20130729001

[22] Choudary, V.R., Mammon, A.S. and Sansare, S.D. (1992) Selective Oxidation of Methane to CO and $\mathrm{H}_{2}$ over Ni/MgO 
at Low Temperatures. Angewandte Chemie International Edition in English, 31, 1189-1190. http://dx.doi.org/10.1002/anie.199211891

[23] Hickman, D.A. and Schmidt, L.D. (1992) Synthesis Gas Formation by Direct Oxidation of Methane over Pt Monoliths. Journal of Catalysis, 138, 267-282. http://dx.doi.org/10.1016/0021-9517(92)90022-A

[24] Hickman, D.A. and Schumidt, L.D. (1993) Production of Syngas by Direct Catalytic Oxidation of Methane. Science, 259, 343-346. http://dx.doi.org/10.1126/science.259.5093.343

[25] Schwiedernoch, R., Tischer, S., Corea, C. and Deutschmann, O. (2003) Experimental and Numerical Study on the Transient Behavior of Partial Oxidation of Methane in a Catalytic Monolith. Chemical Engineering Science, 58, 633-642. http://dx.doi.org/10.1016/S0009-2509(02)00589-4

[26] Basini, L., Guarnoni, A. and Aragno, A. (2000) Molecular and Temperature Aspects in Catalytic Partial Oxidation of Methane. Journal of Catalysis, 190, 284-295. http://dx.doi.org/10.1006/jcat.1999.2745

[27] Grunwaldt, J.-D., Basini, L. and Clausen, B.S. (2001) In Situ EXAFS Study of $\mathrm{Rh} / \mathrm{Al}_{2} \mathrm{O}_{3}$ Catalysts for Catalytic Partial Oxidation of Methane. Journal of Catalysis, 200, 321-329. http://dx.doi.org/10.1006/jcat.2001.3211

[28] Grunwaldt, J.-D., Kappen, P., Basini, L. and Clausen, B.S. (2002) Iridium Clusters for Catalytic Partial Oxidation of Methane-An in Situ Transmission and Fluorescence XAFS Study. Catalysis Letters, 78, 13-21. http://dx.doi.org/10.1023/A:1014909415661

[29] Bizzi, M., Basini, L., Saracco, G. and Specchia, V. (2003) Modeling of Transport Phenomenon Limited Reactivity in Short Contact Time Catalytic Partial Oxidation Reactors. Industrial \& Engineering Chemistry Research, 42, 62-71. http://dx.doi.org/10.1021/ie0203678

[30] Basini, L., Aasberg-Petersen, K., Guarinoni, A. and Ostberg, M. (2001) Catalytic Partial Oxidation of Natural Gas at Elevated Pressure and Low Residence Time. Catalysis Today, 64, 9-20. http://dx.doi.org/10.1016/S0920-5861(00)00504-6

[31] Basini, L. (2005) Issues in $\mathrm{H}_{2}$ and Synthesis Gas Technologies for Refinery, GTL and Small and Distributed Industrial Needs. Catalysis Today, 106, 34-40. http://dx.doi.org/10.1016/j.cattod.2005.07.179

[32] Basini, L. (2006) Fuel Rich Catalytic Combustion: Principles and Technological Developments in Short Contact Time (SCT) Catalytic Processes. Catalysis Today, 117, 384-393. http://dx.doi.org/10.1016/j.cattod.2006.06.043

[33] Iaquaniello, G., Antonetti, E., Cucchiella, B., Palo, E., Salladini, A., Guarinoni, A., Lainati, A. and Basini, L. (2012) Natural Gas Catalytic Partial Oxidation: A Way to Syngas and Bulk Chemicals Production. In: Gupta, S.B., Ed., Natural Gas-Extraction to End Use, Chap. 12, InTech, Rijeka, 267-286. http://dx.doi.org/10.5772/48708

[34] Palm, C., Cremer, P., Peters, R. and Stolten, D. (2002) Small-Scale Testing of a Precious Metal Catalyst in the Auto-Thermal Reforming of Various Hydrocarbon Feeds. Journal of Power Sources, 106, 231-237. http://dx.doi.org/10.1016/S0378-7753(01)01018-7

[35] Song, X. and Guo, Z. (2006) Technologies for Direct Production of Flexible $\mathrm{H}_{2} / \mathrm{CO}$ Synthesis Gas. Energy Conversion and Management, 47, 560-569. http://dx.doi.org/10.1016/j.enconman.2005.05.012

[36] Joensen, F. and Rostrup-Nielsen, J.R. (2002) Conversion of Hydrocarbons and Alcohols for Fuel Cells. Journal of Power Sources, 105, 195-201. http://dx.doi.org/10.1016/S0378-7753(01)00939-9

[37] Rostrup-Nielsen, J.R. (2000) New Aspects of Syngas Production and Use. Catalysis Today, 63, 159-164. http://dx.doi.org/10.1016/S0920-5861(00)00455-7

[38] Rice, S.F. and Mann, D.P. (2007) Auto-Thermal Reforming of Natural Gas to Synthesis Gas. KBR Paper \#2031.

[39] Hou, Z., Chen, P., Fang, H., Zheng, X. and Yashima, T. (2006) Production of Synthesis Gas via Methane Reforming with $\mathrm{CO}_{2}$ on Noble Metals and Small Amount of Noble-(Rh) Promoted Ni Catalysts. International Journal of Hydrogen Energy, 31, 555-561. http://dx.doi.org/10.1016/j.ijhydene.2005.06.010

[40] Luna, A.E.C. and Iriarte, M.E. (2008) Carbon Dioxide Reforming of Methane over a Metal Modified Ni- $\mathrm{Al}_{2} \mathrm{O}_{3} \mathrm{Cata}^{-}$ lyst. Applied Catalysis A: General, 343, 10-15. http://dx.doi.org/10.1016/j.apcata.2007.11.041

[41] Gadalla, A.M. and Bower, B. (1988) The Role of Catalyst Support on the Activity of Nickel for Reforming Methane with $\mathrm{CO}_{2}$. Chemical Engineering Science, 43, 3049-3062. http://dx.doi.org/10.1016/0009-2509(88)80058-7

[42] Ritter, S.K. (2007) What Can We Do with Carbon Dioxide? Chemical \& Engineering News, 85, 11-17. http://dx.doi.org/10.1021/cen-v085n001.p011

[43] Pichasa, C., Pomonisa, P., Petrakisa, D. and Ladavosb, A. (2010) Kinetic Study of the Catalytic Dry Reforming of $\mathrm{CH}_{4}$ with $\mathrm{CO}_{2}$ over $\mathrm{L}_{2-\mathrm{x}} \mathrm{Sr}_{\mathrm{x}} \mathrm{NiO}_{4}$ Perovskite-Type Oxides. Applied Catalysis A: General, 386, 116-123. http://dx.doi.org/10.1016/j.apcata.2010.07.043

[44] Stagg, S.M., Romeo, E. and Resasco, D.E. (1998) Effect of Promotion with Sn on Supported Pt Catalyst for $\mathrm{CO}_{2}$ Reforming of $\mathrm{CH}_{4}$. Journal of Catalysis, 178, 137-145. http://dx.doi.org/10.1006/jcat.1998.2146

[45] Abashar, M.E.E. (2004) Coupling of Steam and Dry Reforming of Methane in Catalytic \& Fluidized Bed Membrane 
Reactors. International Journal of Hydrogen Energy, 29, 799-808. http://dx.doi.org/10.1016/j.ijhydene.2003.09.010

[46] Choudhary, V.R. and Mondal, K.C. (2006) $\mathrm{CO}_{2}$ Reforming of Methane Combined with Steam Reforming or Partial Oxidation of Methane to Syngas over $\mathrm{NdCoO}_{3}$ Perovskite-Type Mixed Metal-Oxide Catalyst. Applied Energy, 83, 1024-1032. http://dx.doi.org/10.1016/j.apenergy.2005.09.008

[47] Özkara-Aydınoglu, S. (2010) Thermodynamic Equilibrium Analysis of Combined Carbon Dioxide Reforming with Steam Reforming of Methane to Synthesis Gas. International Journal of Hydrogen Energy, 35, 12821-12828. http://dx.doi.org/10.1016/j.ijhydene.2010.08.134

[48] Demidov, D.V., Mishin, I.V. and Mikhailov, M.N. (2011) Gibbs Free Energy Minimization as a Way to Optimize the Combined Steam and Carbon Dioxide Reforming of Methane. International Journal of Hydrogen Energy, 36, 5941-5950. http://dx.doi.org/10.1016/j.ijhydene.2011.02.053

[49] Al-Nakoua, M.A. and El-Naas, M.H. (2012) Combined Steam and Dry Reforming of Methane in Narrow Channel Reactors. International Journal of Hydrogen Energy, 37, 7538-7544. http://dx.doi.org/10.1016/j.ijhydene.2012.02.031

[50] Gangadharan, P., Krishna, C.K. and Lou, H.H. (2012) Evaluation of the Economic and Environmental Impact of Combining Dry Reforming with Steam Reforming of Methane. Chemical Engineering Research and Design, 90, 1956-1968. http://dx.doi.org/10.1016/j.cherd.2012.04.008

[51] He, S., Wu, H., Yu, W., Mo, L., Lou, H. and Zheng, X. (2009) Combination of $\mathrm{CO}_{2}$ Reforming and Partial Oxidation of Methane to Produce Syngas over $\mathrm{Ni} / \mathrm{SiO}_{2}$ and $\mathrm{Ni}-\mathrm{Al}_{2} \mathrm{O}_{3} / \mathrm{SiO}_{2}$ Catalysts with Different Precursors. International Journal of Hydrogen Energy, 34, 839-843. http://dx.doi.org/10.1016/j.ijhydene.2008.10.072

[52] Múnera, J.F., Carrara, C., Cornaglia, L.M. and Lombardo, E.A. (2010) Combined Oxidation and Reforming of Methane to Produce Pure $\mathrm{H}_{2}$ in a Membrane Reactor. Chemical Engineering Journal, 161, 204-211. http://dx.doi.org/10.1016/j.cej.2010.04.022

[53] Sanders, M. and O’Hayre, R. (2010) Development of a Multi Species Transport Space Theory and Its Application to Permeation Behavior in Proton-Conducting Doped Perovskites. Journal of Materials Chemistry, 20, 6271-6281. http://dx.doi.org/10.1039/c0jm00064g

[54] Gallucci, F., Tosti, S. and Basile, A. (2008) Pd-Ag Tubular Membrane Reactors for Methane Dry Reforming: A Reactive Method for $\mathrm{CO}_{2}$ Consumption and $\mathrm{H}_{2}$ Production. Journal of Membrane Science, 317, 96-105. http://dx.doi.org/10.1016/j.memsci.2007.03.058

[55] Mundschau, M.V., Xie, X., Everson, C.R. and Sammells, A.F. (2006) Dense Inorganic Membranes for Production of Hydrogen from Methane and Coal with Carbon Dioxide Sequestration. Catalysis Today, 118, 12-23. http://dx.doi.org/10.1016/j.cattod.2006.01.042

[56] Hsieh, H.P. (1996) Inorganic Membranes for Separation and Reaction. Elsevier B.V., Amsterdam.

[57] Nomura, M., Masahiro, S., Aida, H., Nakatani, K., Gopalakrishnan, S., Sugawara, T., Ishikawa, T., Kawamura, M. and Nakao, S. (2006) Preparation of a Catalyst Composite Silica Membrane Reactor for Steam Reforming Reaction by Using a Counter-Diffusion CVD Method. Industrial \& Engineering Chemistry Research, 45, 3950-3954. http://dx.doi.org/10.1021/ie051345z

[58] Tsuru, T., Yamaguchi, K., Yoshioka, T. and Asaeda, M. (2004) Methane Steam Reforming by Microporous Catalytic Membrane Reactors. AIChE Journal, 50, 2794-2805. http://dx.doi.org/10.1002/aic.10215

[59] Kanezashi, M., Yoshioka, T., Tsuru, T. and Asaeda, M. (2004) Stability of Ni-Doped Silica Membranes for $\mathrm{H}_{2}$ Separation at High Temperature. Transactions of the Materials Research Society of Japan, 29, 3267-3270.

[60] Kanezashi, M. and Asaeda, M. (2006) Hydrogen Permeation Characteristics and Stability of Ni-Doped Silica Membranes in Steam at High Temperature. Journal of Membrane Science, 271, 86-93. http://dx.doi.org/10.1016/j.memsci.2005.07.011

[61] Vigneault, A. and Grace, J.R. (2015) Hydrogen Production in Multi-Channel Membrane Reactor via Steam Methane Reforming and Methane Catalytic Combustion. International Journal of Hydrogen Energy, 40, 233-243. http://dx.doi.org/10.1016/j.ijhydene.2014.10.040

[62] Song, C. (2001) Tri-Reforming: A New Process for Reducing $\mathrm{CO}_{2}$ Emission. Chemical Innovation, 31, 21-26.

[63] Rostrup-Nielsen, J.R. and Bak Hansen, J.H. (1993) $\mathrm{CO}_{2}$ Reforming of Methane over Transition Metals. Journal of Catalysis, 144, 38-49. http://dx.doi.org/10.1006/jcat.1993.1312

[64] Rostrup-Nielsen, J.R. (1994) Aspects of $\mathrm{CO}_{2}$ Reforming of Methane. Studies in Surface Science and Catalysis, 81, 25-41. http://dx.doi.org/10.1016/s0167-2991(08)63847-1

[65] Wang, S. and Lu, G.Q.M. (1996) Carbon Dioxide Reforming of Methane to Produce Synthesis Gas over Metal-Supported Catalysts: State of the Art. Energy \& Fuels, 10, 896-904. http://dx.doi.org/10.1021/ef950227t

[66] Bradford, M.C.J. and Vannice, M.A. (1999) $\mathrm{CO}_{2}$ Reforming of $\mathrm{CH}_{4}$. Catalysis Reviews: Science and Engineering, 40, 1-42. http://dx.doi.org/10.1081/CR-100101948 
[67] Tomishige, K., Himeno, Y., Yamazaki, O., Chen, Y., Wakatsuki, T. and Fujimoto, K. (1999) Development of a New Generation Reforming Catalyst: Catalytic Performance and Carbon Deposition Behavior on Nickel-Magnesia Catalysts. Kinetics and Catalysis, 40, 432-439.

[68] DOE/FE (1999) Capturing Carbon Dioxide. Office of Fossil Energy, US Department of Energy, Washington DC.

[69] FETC (Federal Energy Technology Center) (1999) Vision 21 Program Plan-Clean Energy Plants for the 21st Century. Office of Fossil Energy, US Department of Energy, Washington DC.

[70] Song, C. (1999) Chemicals, Fuels and Electricity from Coal, A Proposed Tri-Generation Concept for Utilization of $\mathrm{CO}_{2}$ from Power Plants. 16th International Pittsburgh Coal Conference, Pittsburgh, 11-15 October 1999, Paper No. 16-6.

[71] Ashcroft, A.T., Cheetham, A.K., Green, M.L.H. and Vernon, P.D.F. (1991) Partial Oxidation of Methane to Synthesis Gas Using Carbon Dioxide. Nature, 352, 225-226. http://dx.doi.org/10.1038/352225a0

[72] Inui, T., Saigo, K., Fujii, Y. and Fujioka, K. (1995) Catalytic Combustion of Natural Gas as the Role of One-Site Heat Supply in Rapid Catalytic $\mathrm{CO}_{2}-\mathrm{H}_{2} \mathrm{O}$ Reforming of Methane. Catalysis Today, 26, 295-302. http://dx.doi.org/10.1016/0920-5861(95)00151-9

[73] O’Connor, A.M. and Ross, J.R.H. (1998) The Effect of $\mathrm{O}_{2}$ Addition on the Carbon Dioxide Reforming of Methane over Pt/ZrO $\mathrm{Zr}_{2}$ Catalysts. Catalysis Today, 46, 203-210. http://dx.doi.org/10.1016/S0920-5861(98)00342-3

[74] Choudhary, V.R., Rajput, A.M. and Prabhakar, B. (1994) NiO/CaO Catalyzed Formation of Syngas by Coupled Exothermic Oxidation Conversion and Endothermic $\mathrm{CO}_{2}$ and Steam Reforming of Methane. Angewandte Chemie International Edition in English, 33, 2104-2106. http://dx.doi.org/10.1002/anie.199421041

[75] Song, C.S. and Pan, W. (2004) Tri-Reforming of Methane: A Novel Concept for Catalytic Production of Industrially Useful Synthesis Gas with Desired $\mathrm{H}_{2}$ /CO Ratios. Catalysis Today, 98, 463-484. http://dx.doi.org/10.1016/j.cattod.2004.09.054

[76] Halmann, M. and Steinfeld, A. (2006) Thermo-Neutral Tri-Reforming of Flue Gases from Coal- and Gas-Fired Power Stations. Catalysis Today, 115, 170-178. http://dx.doi.org/10.1016/j.cattod.2006.02.064

[77] Jiang, H., Li, H., Xu, H. and Zhang, Y. (2007) Preparation of Ni/Mg $\mathrm{Mi}_{1-\mathrm{x}} \mathrm{O}$ Catalysts and Investigation on Their Stability in Tri-Reforming of Methane. Fuel Processing Technology, 88, 988-995. http://dx.doi.org/10.1016/j.fuproc.2007.05.007

[78] Kang, J.S., Kim, D.H., Lee, S.D., Hong, S.I. and Moon, D.J. (2007) Nickel-Based Tri-Reforming Catalyst for Production of Synthesis Gas. Applied Catalysis A: General, 332, 153-158. http://dx.doi.org/10.1016/j.apcata.2007.08.017

[79] Cho, W.J., Song, T.Y., Mitsos, A., McKinnon, J.T., Ko, G.H., Tolsma, J.E., Denholm, D. and Park, T. (2009) Optimal Design and Operation of a Natural Gas Tri-Reforming Reactor for DME Synthesis. Catalysis Today, 139, 261-267. http://dx.doi.org/10.1016/j.cattod.2008.04.051

[80] Horn, R., Williams, K.A., Degenstein, N.J. and Schmidt, L.D. (2006) Syngas by Catalytic Partial Oxidation of Methane on Rhodium: Mechanistic Conclusions from Spatially Resolved Measurements and Numerical Simulations. Journal of Catalysis, 242, 92-102. http://dx.doi.org/10.1016/j.jcat.2006.05.008

[81] Donazzi, A., Maestri, M., Michael, B.C., Beretta, A., Groppi, P., Tronconi, E., Schmidt, L.D. and Vlachos, D.G. (2010) Micro Kinetic Modeling of Spatially Resolved Auto-Thermal $\mathrm{CH}_{4}$ Catalytic Partial Oxidation Experiments over Rh-Coated Foams. Journal of Catalysis, 275, 270-279. http://dx.doi.org/10.1016/j.jcat.2010.08.007

[82] Salazar-Villalpando, M.A. and Miller, A.C. (2011) Catalytic Partial Oxidation of Methane and Isotopic Oxygen Exchange Reactions over ${ }^{18} \mathrm{O}$ Labeled Rh/Gadolinium Doped Ceria. International Journal of Hydrogen Energy, 36, 3880-3885. http://dx.doi.org/10.1016/j.ijhydene.2010.11.040

[83] Ishihara, A., Qian, E.W., Nuryatin, I., Finahari, I., Sutrisna, P. and Kabe, T. (2005) Addition Effect of Ruthenium on Nickel Steam Reforming Catalysts. Fuel, 84, 1462-1468. http://dx.doi.org/10.1016/j.fuel.2005.03.006

[84] Lanza, R., Järås, S.G. and Canu, P. (2008) Micro Emulsion-Prepared Ruthenium Catalyst for Syngas Production via Methane Partial Oxidation. Applied Catalysis A: General, 337, 10-18. http://dx.doi.org/10.1016/j.apcata.2007.11.030

[85] Shamsi, A. (2009) Partial Oxidation of Methane and the Effect of Sulfur on Catalytic Activity and Selectivity. Catalysis Today, 139, 268-273. http://dx.doi.org/10.1016/j.cattod.2008.03.033

[86] Souza, M.M.V.M., Neto, O.R.M. and Schmal, M. (2006) Synthesis Gas Production from Natural Gas on Supported Pt Catalysts. Journal of Natural Gas Chemistry, 15, 21-27. http://dx.doi.org/10.1016/S1003-9953(06)60003-0

[87] Silva, F.D., Ruiz, J.A.C., de Sousa, K.R., Bueno, J.M.C., Mattos, L.V., Noronha, F.B. and Hori, C.E. (2009) Partial Oxidation of Methane on Pt Catalysts: Effect of the Presence of Ceria-Zirconia Mixed Oxide and of Metal Content. Applied Catalysis A: General, 364, 122-129. http://dx.doi.org/10.1016/j.apcata.2009.05.038

[88] Salazar-Villalpando, M.D. and Miller, A.C. (2011) Hydrogen Production by Methane Decomposition and Catalytic Partial Oxidation of Methane over Pt/Ce $\mathrm{Gd}_{1-\mathrm{x}} \mathrm{O}_{2}$ and $\mathrm{Pt} / \mathrm{Ce} \mathrm{Zr}_{1-\mathrm{x}} \mathrm{O}_{2}$. Chemical Engineering Journal, 166, 738-743. 
http://dx.doi.org/10.1016/j.cej.2010.11.076

[89] Ryu, J.H., Lee, K.Y., Kim, H.J., Yang, J.I. and Jung, H. (2008) Promotion of Palladium-Based Catalysts on Metal Monolith for Partial Oxidation of Methane to Syngas. Applied Catalysis B: Environmental, 80, 306-312. http://dx.doi.org/10.1016/j.apcatb.2007.10.010

[90] Richardson, J.T. and Paripatyadar, S.A. (1990) Carbon Dioxide Reforming of Methane with Supported Rhodium. Applied Catalysis, 61, 293-309. http://dx.doi.org/10.1016/S0166-9834(00)82152-1

[91] Barbero, J., Peña, M.A., Campos-Martín, J.M., Fierro, J.L.G. and Arias, P.L. (2003) Support Effect in Supported Ni Catalysts on Their Performance for Methane Partial Oxidation. Catalysis Letters, 87, 211-218. http://dx.doi.org/10.1023/A:1023407609626

[92] Zeppieri, M., Villa, P.L., Verdone, N., Scarsella, M. and De Filippis, P. (2010) Kinetics of Methane Steam Reforming Reaction over Nickel- and Rhodium-Based Catalysts. Applied Catalysis A: General, 387, 147-154. http://dx.doi.org/10.1016/j.apcata.2010.08.017

[93] Ertl, G., Knözinger, H., Schüth, F. and Weitkamp, J. (Eds.) (2008) Handbook of Heterogeneous Catalysis. 2nd Edition, Wiley-VCH, Weinheim. http://dx.doi.org/10.1002/9783527610044

[94] Molenbroek, A.M., Helveg, S., Topsøe, H. and Clausen, B.S. (2009) Nanoparticles in Heterogeneous Catalysis. Topics in Catalysis, 52, 1303-1311. http://dx.doi.org/10.1007/s11244-009-9314-1

[95] Bitter, J.H., Hally, W., Seshan, K., van Ommen, J.G. and Lercher, J.A. (1996) The Role of the Oxidic Support on the Deactivation of Pt Catalysts during the $\mathrm{CO}_{2}$ Reforming of Methane. Catalysis Today, 29, 349-353. http://dx.doi.org/10.1016/0920-5861(95)00303-7

[96] Ruckenstein, E. and Hu, Y.H. (1996) Role of Support in $\mathrm{CO}_{2}$ Reforming of $\mathrm{CH}_{4}$ to Syngas over Ni Catalysts. Journal of Catalysis, 162, 230-238. http://dx.doi.org/10.1006/jcat.1996.0280

[97] Passos, F.B., de Oliveira, E.R., Mattos, L.V. and Noronha, F.B. (2005) Partial Oxidation of Methane to Synthesis Gas on $\mathrm{Pt} / \mathrm{Ce}_{\mathrm{x}} \mathrm{Zr}_{1-\mathrm{x}} \mathrm{O}_{2}$ Catalysts: The Effect of the Support Reducibility and of the Metal Dispersion on the Stability of the Catalysts. Catalysis Today, 101, 23-30. http://dx.doi.org/10.1016/j.cattod.2004.12.006

[98] Jing, Q.S. and Zheng, X.M. (2006) Combined Catalytic Partial Oxidation and $\mathrm{CO}_{2}$ Reforming of Methane over $\mathrm{ZrO}_{2}$-Modified Ni/SiO ${ }_{2}$ Catalysts Using Fluidized-Bed Reactor. Energy, 31, 2184-2192. http://dx.doi.org/10.1016/j.energy.2005.07.005

[99] Araujo, J.C.S., Zanchet, D., Rinaldi, R., Schuchardt, U., Hori, C.E., Fierro, J.L.G. and Bueno, J.M.C. (2008) The Effects of $\mathrm{La}_{2} \mathrm{O}_{3}$ on the Structural Properties of $\mathrm{La}_{2} \mathrm{O}_{3}-\mathrm{Al}_{2} \mathrm{O}_{3}$ Prepared by the Sol-Gel Method and on the Catalytic Performance of $\mathrm{Pt} / \mathrm{La}_{2} \mathrm{O}_{3}-\mathrm{Al}_{2} \mathrm{O}_{3}$ towards Steam Reforming and Partial Oxidation of Methane. Applied Catalysis B: Environmental, 84, 552-562. http://dx.doi.org/10.1016/j.apcatb.2008.05.011

[100] Al-Fatesh, A.S., Naeem, M.A., Fakeeha, A.H. and Abasaeed, A.E. (2014) Role of $\mathrm{La}_{2} \mathrm{O}_{3}$ as Promoter and Support in $\mathrm{Ni} / \gamma-\mathrm{Al}_{2} \mathrm{O}_{3}$ Catalysts for Dry Reforming of Methane, Catalysis, Kinetics and Reaction Engineering. Chinese Journal of Chemical Engineering, 22, 28-37. http://dx.doi.org/10.1016/S1004-9541(14)60029-X

[101] Eriksson, S., Rojas, S., Boutonnet, M. and Fierro, J.L.G. (2007) Effect of Ce Doping on Rh/ZrO ${ }_{2}$ Catalysts for Partial Oxidation of Methane. Applied Catalysis A: General, 326, 8-16. http://dx.doi.org/10.1016/j.apcata.2007.03.019

[102] Larrondo, S.A., Kodjaian, A., Fabregas, I., Zimicz, M.G., Lamas, D.G., Walsoe de Reca, B.E. and Amadeo, N.E. (2008) Methane Partial Oxidation Using $\mathrm{Ni} / \mathrm{Ce}_{0.9} \mathrm{Zr}_{0.1} \mathrm{O}_{2}$ Catalysts. International Journal of Hydrogen Energy, 33, 3607-3613. http://dx.doi.org/10.1016/j.ijhydene.2008.04.025

[103] Valderrama, G., de Navarro, C.U. and Goldwasser, M.R. (2013) Review: $\mathrm{CO}_{2}$ Reforming of $\mathrm{CH}_{4}$ over Co-La-Based Perovskite-Type Catalyst Precursors. Journal of Power Sources, 234, 31-37. http://dx.doi.org/10.1016/j.jpowsour.2013.01.142

[104] Chawla, S.K., George, M., Patel, F. and Patel, S. (2013) Production of Synthesis Gas by Carbon Dioxide Reforming of Methane over Nickel Based and Perovskite Catalysts. Procedia Engineering, 51, 461-466. http://dx.doi.org/10.1016/j.proeng.2013.01.065

[105] Naeem, M.A., Al-Fatesh, A.S., Abasaeed, A.E. and Fakeeha, A.H. (2014) Activities of Ni-Based Nano Catalysts for $\mathrm{CO}_{2}-\mathrm{CH}_{4}$ Reforming Prepared by Polyol Process. Fuel Processing Technology, 122, 141-152. http://dx.doi.org/10.1016/j.fuproc.2014.01.035

[106] Park, S., Bang, Y., Han, S.J., Yoo, J., Song, J.H., Song, J.C., Lee, J. and Song, I.K. (2015) Hydrogen Production by Steam Reforming of Liquefied Natural Gas (LNG) over Mesoporous Nickel-Iron-Alumina Catalyst. International Journal of Hydrogen Energy, 40, 5869-5877. http://dx.doi.org/10.1016/j.ijhydene.2015.03.016

[107] Lago, R., Bini, G., Peña, M.A. and Fierro, J.L.G. (1997) Partial Oxidation of Methane to Synthesis Gas Using LnCoO $_{3}$ Perovskites as Catalyst Precursors. Journal of Catalysis, 167, 198-209. http://dx.doi.org/10.1006/jcat.1997.1580

[108] Shishido, T., Sukenobu, M., Morioka, H., Kondo, M., Wang, Y., Takaki, K. and Takehira, K. (2002) Partial Oxidation 
of Methane over Ni/Mg-Al Oxide Catalysts Prepared by Solid Phase Crystallization Method from Mg-Al Hydrotalcite-Like Precursors. Applied Catalysis A: General, 223, 35-42. http://dx.doi.org/10.1016/S0926-860X(01)00732-3

[109] Pereniguez, R., Gonzalez-de la Cruz, V.M., Holgado, J.P. and Caballero, A. (2010) Synthesis and Characterization of a $\mathrm{LaNiO}_{3}$ Perovskite as Precursor for Methane Reforming Reactions Catalysts. Applied Catalysis B: Environmental, 93, 346-353. http://dx.doi.org/10.1016/j.apcatb.2009.09.040

[110] Su, Y.J., Pan, K.L. and Chang, M.B. (2014) Modifying Perovskite-Type Oxide Catalyst $\mathrm{LaNiO}_{3}$ with Ce for Carbon Dioxide Reforming of Methane. International Journal of Hydrogen Energy, 39, 4917-4925. http://dx.doi.org/10.1016/j.ijhydene.2014.01.077

[111] Guo, Y.H., Xia, C. and Liu, B.S. (2014) Catalytic Properties and Stability of Cubic Mesoporous $\mathrm{La}_{\mathrm{x}} \mathrm{Ni}_{\mathrm{y}} \mathrm{O}_{\mathrm{z}} / \mathrm{KIT}-6$ Catalysts for $\mathrm{CO}_{2}$ Reforming of $\mathrm{CH}_{4}$. Chemical Engineering Journal, 237, 421-429. http://dx.doi.org/10.1016/j.cej.2013.09.108

[112] Xu, B.-Q., Wei, J.-M., Yu, Y.-T., Li, Y., Li, J.-L. and Zhu, Q.-M. (2003) Size Limit of Support Particles in an Oxide-Supported Metal Catalyst: Nanocomposite $\mathrm{Ni} / \mathrm{ZrO}_{2}$ for Utilization of Natural gas. The Journal of Physical Chemistry B, 107, 5203-5207. http://dx.doi.org/10.1021/jp030127l

[113] Xu, B.-Q., Wei, J.-M., Wang, H.-Y., Sun, K.-Q. and Zhu, Q.-M. (2001) Nano-MgO: Novel Preparation and Application as Support of Ni Catalyst for $\mathrm{CO}_{2}$ Reforming of Methane. Catalysis Today, 68, 217-225. http://dx.doi.org/10.1016/S0920-5861(01)00303-0

[114] Xu, L., Song, H. and Chou, L. (2013) Ordered Mesoporous MgO- $\mathrm{Al}_{2} \mathrm{O}_{3}$ Composite Oxides Supported Ni Based Catalysts for $\mathrm{CO}_{2}$ Reforming of $\mathrm{CH}_{4}$ : Effects of Basic Modifier and Mesopore Structure. International Journal of Hydrogen Energy, 38, 7307-7325. http://dx.doi.org/10.1016/j.ijhydene.2013.04.034

[115] Rezaei, M., Alavi, S.M., Sahebdelfar, S. and Yan, Z.-F. (2008) Effect of Process Parameters on the Synthesis of Mesoporous Nano Crystalline Zirconia with Tri-Block Copolymer as Template. Journal of Porous Materials, 15, 171-179. http://dx.doi.org/10.1007/s10934-007-9120-8

[116] Rezaei, M., Alavi, S.M., Sahebdelfar, S. and Yan, Z.-F. (2009) Synthesis of Ceria Doped Nano Zirconia Powder by a Polymerized Complex Method. Journal of Porous Materials, 16, 497-505. http://dx.doi.org/10.1007/s10934-008-9224-9

[117] Rezaei, M., Alavi, S.M., Sahebdelfar, S. and Yan, Z.-F. (2008) Effects of $\mathrm{K}_{2} \mathrm{O}$ Promoter on the Activity and Stability of Nickel Catalysts Supported on Mesoporous Nano Crystalline Zirconia in $\mathrm{CH}_{4}$ Reforming with $\mathrm{CO}_{2}$. Energy \& Fuels, 22, 2195-2202. http://dx.doi.org/10.1021/ef800114e

[118] Rezaei, M., Alavi, S.M., Sahebdelfar, S. and Yan, Z.-F. (2009) A Highly Stable Catalyst in Methane Reforming with Carbon Dioxide. Scripta Materialia, 61, 173-176. http://dx.doi.org/10.1016/j.scriptamat.2009.03.033

[119] Inui, T. (2002) Reforming of $\mathrm{CH}_{4}$ by $\mathrm{CO}_{2}, \mathrm{O}_{2}$ and/or $\mathrm{H}_{2} \mathrm{O}$ Catalysis. The Royal Society, 16, 133-154.

[120] Inui, T. (2004) Novel Synthesis Routes for Clean Fuels through Ultra-Rapid Synthesis of Syngas as the Trigger Technology. 14th Saudi-Japan Symposium on Catalysts in Petroleum Refining \& Petrochemicals, King Fahd University of Petroleum \& Minerals (KFUPM), Dhahran, 5-6 December 2004, 11-23.

[121] Inui, T. (2003) Ultra Rapid Reforming of Methane of Hydrocarbons by Thermo-Neutral Reaction Method on a Multi Functional Catalyst for Hydrogen Production and Fuel Cell Systems. Fuel Chemistry Division Preprints, 48, 370-371.

[122] Inui, T. (2001) Effective Conversion of $\mathrm{CO}_{2}$ to Valuable Compounds by Using Multifunctional Catalysts. Song, S., et al., Eds., $\mathrm{CO}_{2}$ Conversion and Utilization, ACS Symposium Series, Vol. 809, American Chemical Society, Washington DC, 130-152. 


\section{List of Abbreviations}

\begin{tabular}{|c|c|}
\hline ATR & Auto-thermal Reforming \\
\hline $\mathrm{BFW}$ & Boiler Feed Water \\
\hline CDPOX & Combined Dry Reforming and Partial Oxidation \\
\hline CPOX & Catalytic Partial Oxidation \\
\hline CSDR & Combined Steam and Dry Reforming \\
\hline CMR & Combined Methane Reforming \\
\hline CTL & Chemicals to Liquid Fuels \\
\hline DME & Di Methyl Ether \\
\hline DMR & Dry Methane Reforming \\
\hline $\mathrm{F}-\mathrm{T}$ & Fischer-Tropsch \\
\hline GHSV & Gas Hourly Space Velocity, $\mathrm{h}^{-1}$ \\
\hline GTL & Gas-to-Liquid \\
\hline HR-TEM & High Resolution Transmission Electron Microscopy \\
\hline HT & Heat Transfer or Heat Exchange \\
\hline IGCC & Integrated Gasification Combined Cycle \\
\hline ITM & Ion Transport Membrane \\
\hline KBR & Kellogg Brown \& Root Company \\
\hline MCC & Methane Catalytic Combustion \\
\hline MCMR & Multi-Channel Membrane Reactor \\
\hline MTBE & Methyl Tertiary-Butyl Ether \\
\hline POX & Partial Oxidation Method \\
\hline PSA & Pressure swing adsorption \\
\hline RWGS & Reverse Water Gas Shift \\
\hline SCT- CPO & Short contact time-catalytic partial oxidation \\
\hline SMR & Steam Methane Reforming \\
\hline TGA & Thermal Gravimetric Analysis \\
\hline TNR & Thermal Neutral Reaction \\
\hline TMR & Tri Reforming \\
\hline WGS & Water Gas Shift \\
\hline WHSV & Weight Hourly Space Velocity cc $\mathrm{g}^{-1} \cdot \mathrm{h}^{-1}$ \\
\hline YSZ & Yttria-Stabilized Zirconia \\
\hline
\end{tabular}

